\title{
Workshop on Capacity-Building for National Development Programs in Selected Infrastructure Sectors
}

October 23, 2003

Kabul, Afghanistan
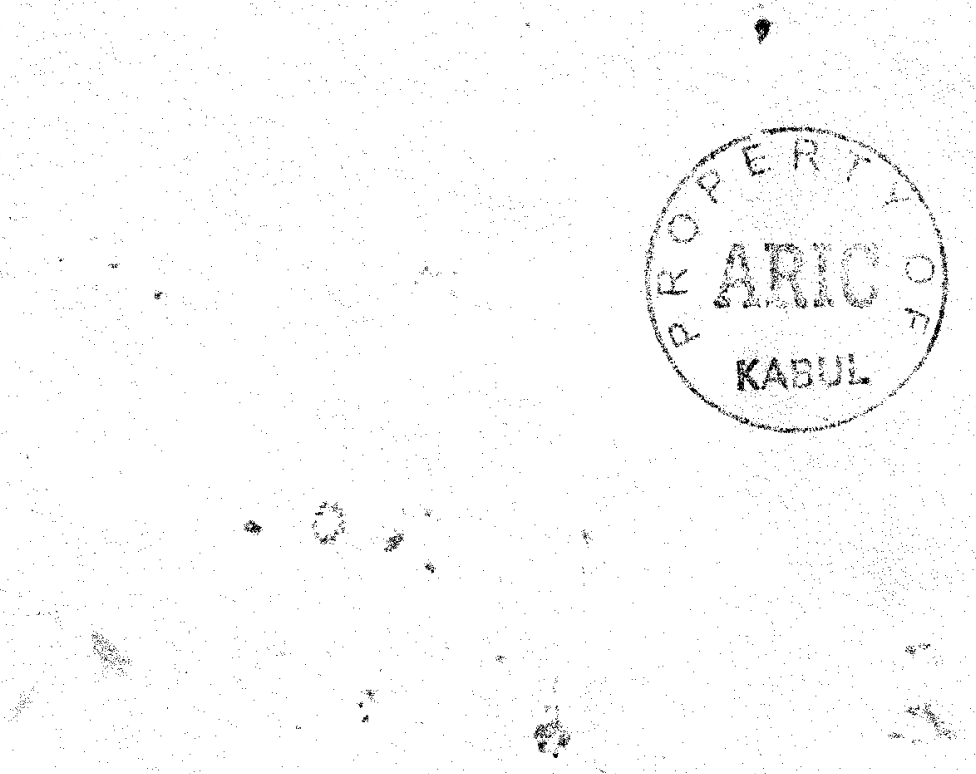

A WORKSHOP JOINTLY ORGANIZED BY

\begin{tabular}{|c|c|c|}
\hline $\begin{array}{c}\text { The Transitional Islamic } \\
\text { State of Afghanistan }\end{array}$ & The World Bank & $\begin{array}{c}\text { The Asian Development } \\
\text { Bank }\end{array}$ \\
\hline
\end{tabular}




\title{
Table of Contents
}

\author{
BACKGROUND \\ Introduction (Dari) \\ Introduction (English) \\ Summary of Workshop Proceedings (Dari) \\ Summary of Workshop Proceedings (English)
}

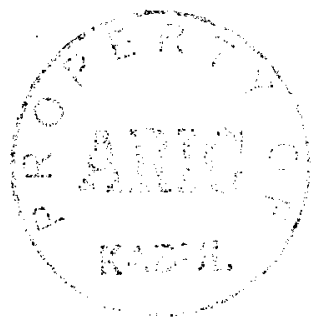

PRIORITY RESTRUCTURING AND REFORM

Qverview (Dari)

Overview (English)

PRELIMINARY RESTRUCTURING AND CAPACITY-BUILLING PL.ANS

Ministry of Urban Development and Housing

Ministry of Water and Power"

Case-Study: Urban Water Supply and Sanitation (MUDH)

A. Agenda (Dari)

B. Agenda (English)

C. Template for Short-Term Capacity-Building Plan (Dari)

D. Template for Short-Term Capacity-Building Plan (English)

E. Key Functions of Capacity

F. Workshop Attendees

1. Afghanistan UWSS Sector Development (Draft) 


\section{Introduction}

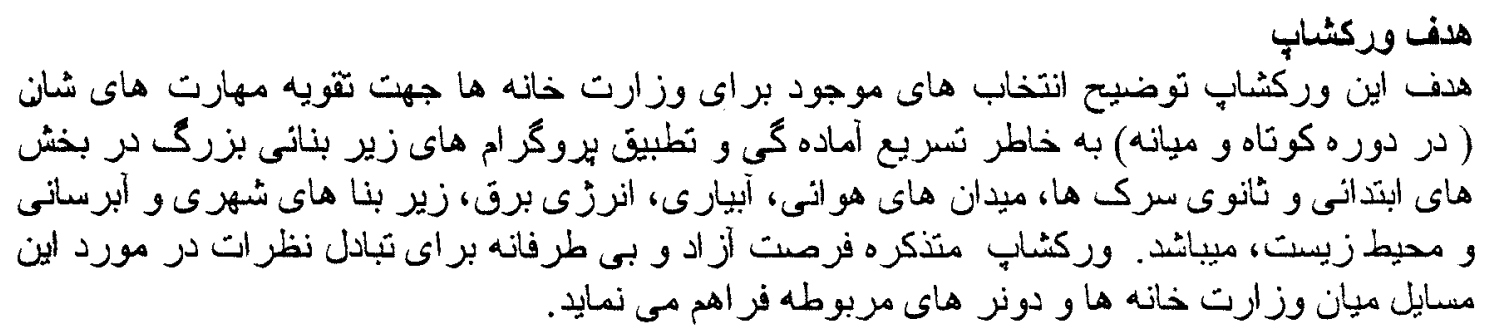

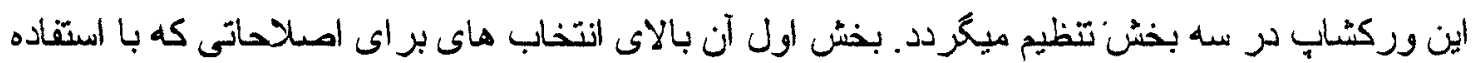

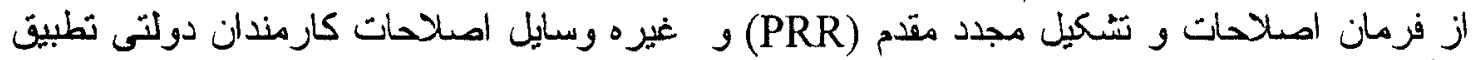

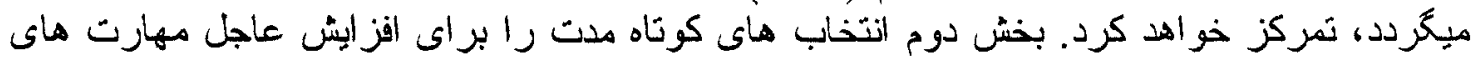

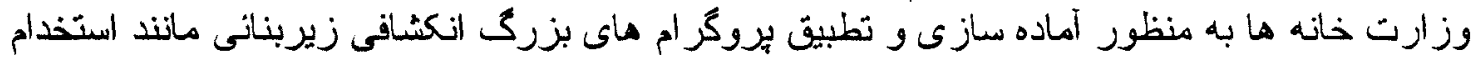

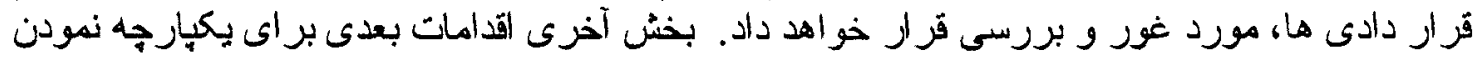

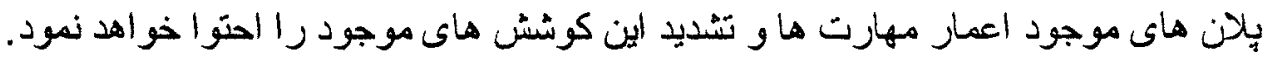

ابن وركشاب به صورت ملتنزك از طرف دولت اسلامى انتقالى افغانستان، بانك انكثافى آسيا و بانك جهانى بركذابر كر ديده است.

The objective of the workshop was to clarify options available to ministries to strengthen their capacity (in both the short- and medium-terms) to accelerate preparation and implementation of large infrastructure programs in the sectors of primary and secondary roads, airports, irrigation, electric power, urban infrastructure, and water supply and sanitation. The workshop was to provide an opportunity for a candid and open exchange, of views on these topics amongst concerned ministries and donors.

The workshop was structured in three parts. The first focused on options for reforms that can be implemented using the Priority Reform and Restructuring (PRR) Decree and other instruments of civil service reform. The second part considered short-term options to rapidly increase the capacity of ministries to prepare and implement large infrastructure de contractors. The final segment covered immediate next steps to be taken to consolidate existing capacity-building plans and intensify those existing efforts.

The workshop was organized jointly by the Government of the Transitional Islamic State of Afghanistan, the Asian Development Bank, and The World Bank. 


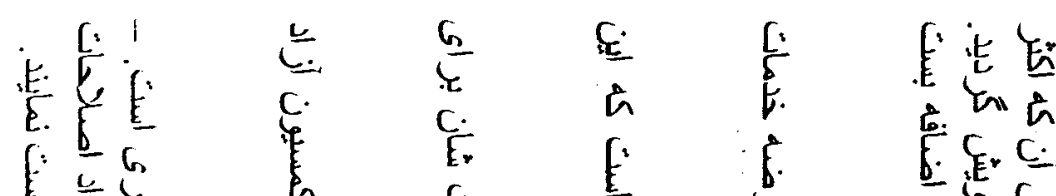

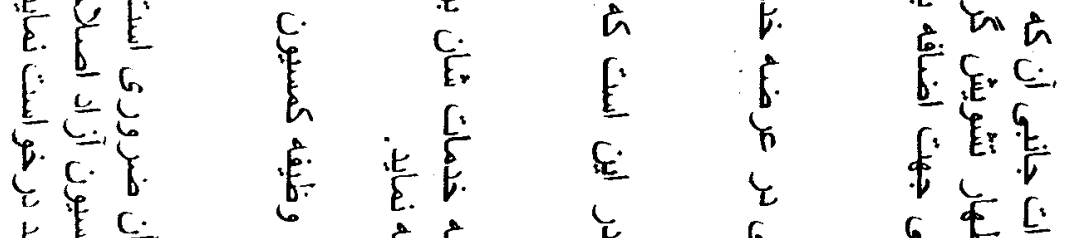

है

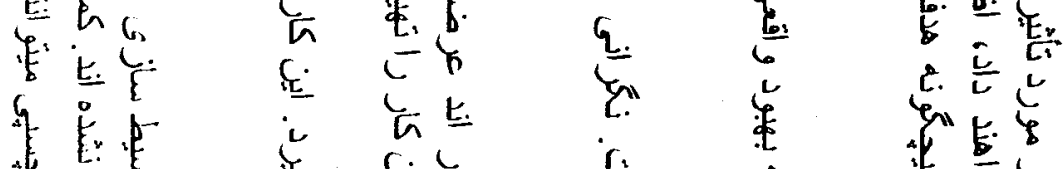

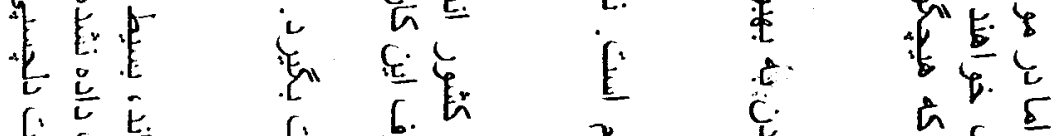

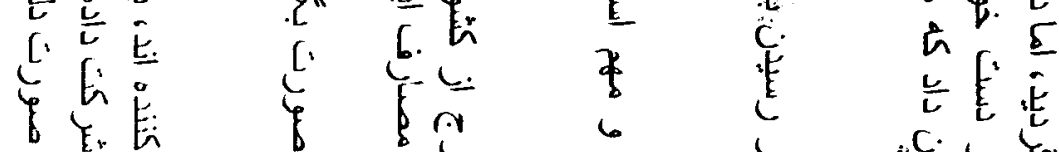

b

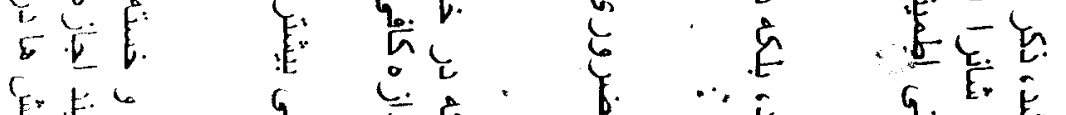

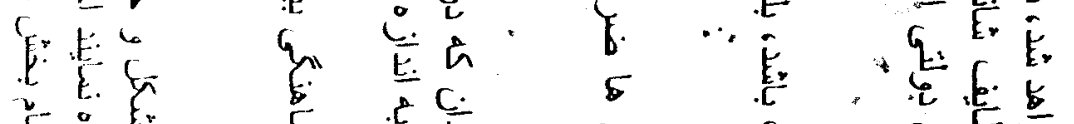

等

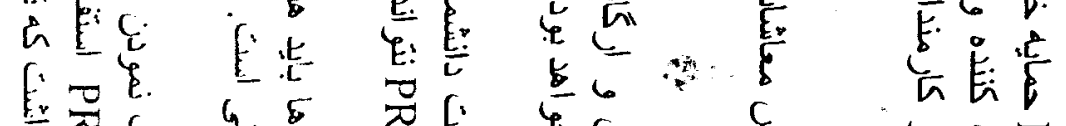

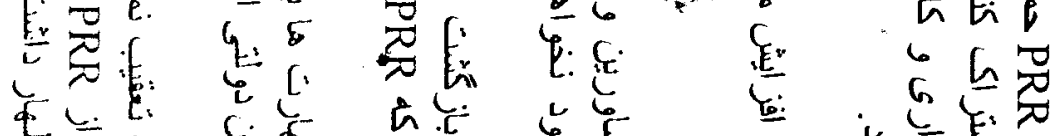

to

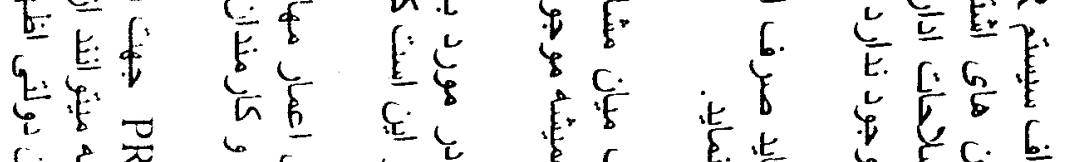

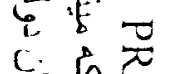

政究

然

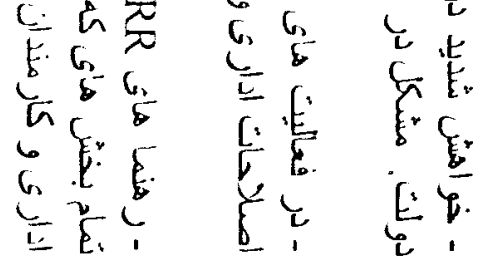

E. ?

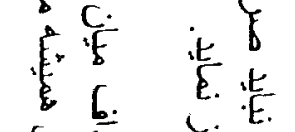

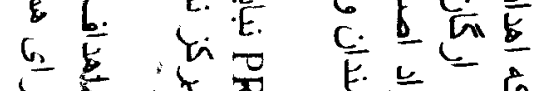

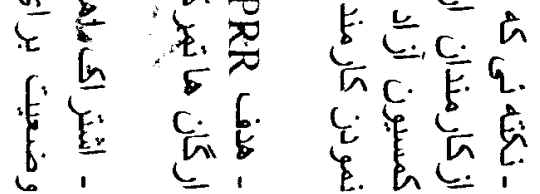

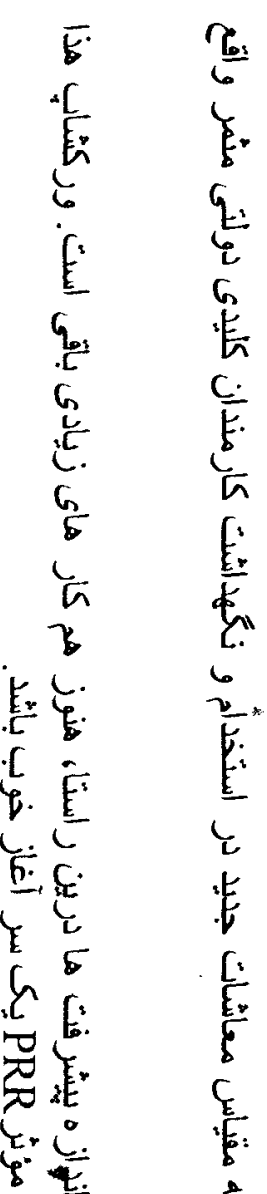

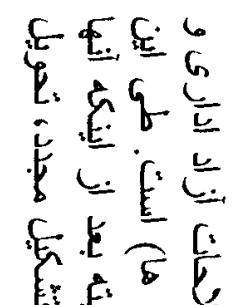

N

6. के

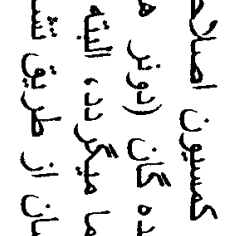

E. E. 㥂员

t.

ह. ह. E. है

है 5 है

髟定

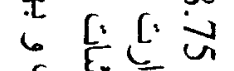

सह

tr

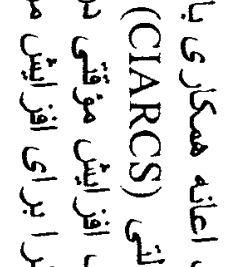

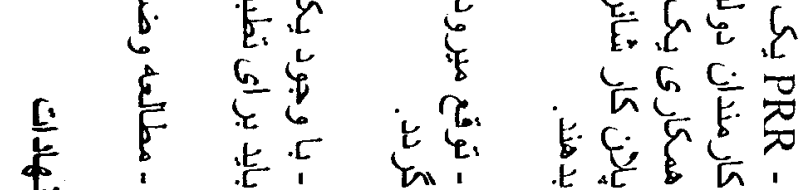

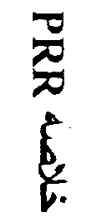

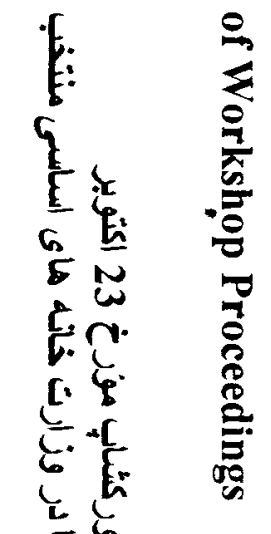




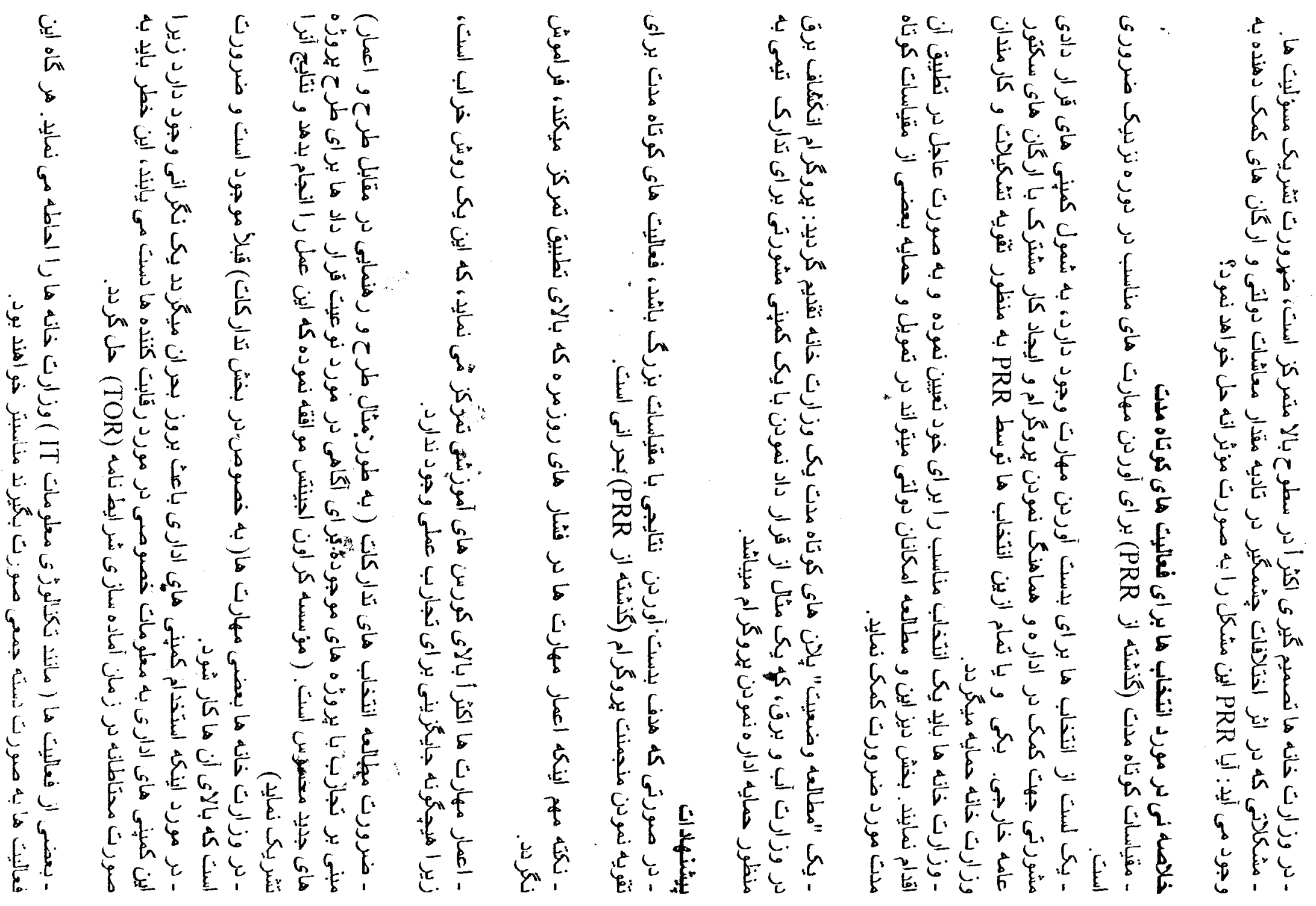




$$
\begin{aligned}
& \text { ـ دونر ها به شمول بانك هاى انكثافى) بايد ضروريات تذاركات رإ براي تدارك مشاورين به } \\
& \text { مورت بسيار كند و أهسته كم نمايند. } \\
& \text { ـ توجه مساويانه بايد به تمام وزارت خانه هاى مسؤول بيزوكر ام هاى سرمايه كذارى بزرى و همجنان }
\end{aligned}
$$

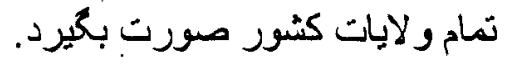

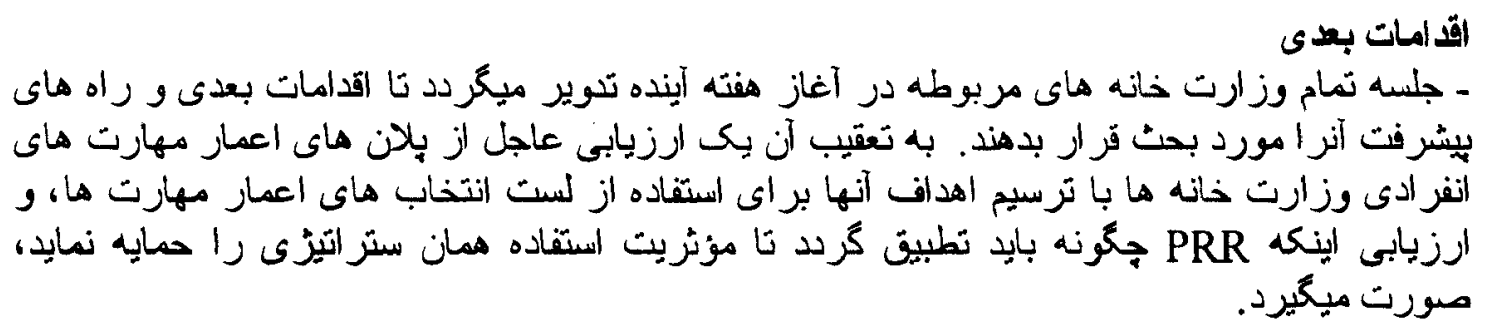

ـ فعاليت هاى عاجل مورد ضرورث: يلان ها و شر ايط نامه TOR بايد در جريان بك يا دو هفته آماده باشّد.

\section{PRR Briefing}

Eklil Hakimi, of the Independent Administrative Reform and Civil Service Commission (IARCSC), gave a presentation outlining the Priority Reform and Restructuring (PRR) system, which is a collaborative capacity-building effort between the IARCSC, ministries and donors. PRR offers temporary salary increases to priority departments in the participating ministries once they have submitted a plan to increase efficiency and improve service delivery through restructuring. This new pay scale is intended to aid in the recruitment and retention of key civil servants, which has to date been a problem for ministries. Mr. Hakimi pointed out that while some progress has already been made, much work remains to be done, and the workshop should serve as a springboard to the effective implementation of PRR.

The Ministry of Public Works subsequently-presented a short case-study of PRR implementation in its Operations and Maintenance Departments.

The floor was then opened for a plenary discussion, and several suggestions were offered for the improvement of the PRR program. One workshop attendee mentioned that his ministry had found the PRR guidelines to be somewhat tedious and difficult to follow; he suggested that they be streamlined and simplified so that departments would be able to embark on the reforms more quickly. Another speaker asserted that there were a number of departments that could benefit from PRR but were not being allowed to participate. The IARCSC noted that all departments at the participating ministries are eligible and encouraged to apply.

Several speakers had more general concerns about PRR. While endorsing the goals of the system, one workshop attendee expressed concern about the side-effect that many employees at participating agencies may lose their jobs-in response to which, the IARCSC offered reassurance that there is no intention to make any staff redundant. Another speaker argued that PRR shouldn't merely be about raising salaries - that it should also focus on achieving tangible improvements in the agencies' work. Others questioned whether PRR offers an effective solution to the twin problems of encouraging Afghan ex-pats to return to the country and retaining current skilled staff, given the great discrepancy in salaries offered by the government and aid agencies.

There were also a number of points made about the more general topic of capacity-building. Several speakers pointed out that while there is no single plan that will work for every ministry, there are a 
number of areas-such as IT-where ministries would benefit by working together. It was suggested that a coordinating body be formed to manage such efforts, with the response made that this is ultimately the task of the IARCSC. Another person argued that for capacity-building efforts to succeed, it is crucial that consultants share the goals of the governmental agencies; there was concern that this is not always the case. A final commenter stated that in his experience, decision-making seemed too often concentrated at the top of ministries, and that there was a need for delegation of responsibilityto both increase the efficiency and capacity of these ministries.

\section{Briefing on Options for Short-term Actions}

His Excellency Finance Minister Dr. Ashraf Ghani presented a briefing on the options for short-term capacity-building available to the ministries. He pointed out that human capital available to the government had been badly damaged, and ministries now lack the capacity necessary to carry-out their responsibilities. Since PRR is more of a medium- and long-term approach to capacity-building, complementary short-term measures are necessary.

H.E. Minister Ghani explained that there is a menu of options available to the ministries for the acquisition of capacity: contracting-in consulting firms to support program management/coordination, contracting-out and twinning with foreign Public Sector Authorities. Any and all of these options can be supported by PRR to strengthen ministry structures and staffing. To proceed, ministries need simply to determine which options are best for them and quickly progress to implementation. The government's Design and Feasibility Studies Unit (DFSU) can help finance and support some of the necessary short-term measures.

A case-study was then presented that highlighted short-term plans currently being implemented at the Minister of Water and Power. The Power Development Program is an example of contracting-in a consulting firm to provide support for program management.

The floor was then opened for a plenary discussion. Several attendees echoed H.E. Minister Ghani's point about the importance of taking short-term actions to strengthen capacity-program management, in particular, was named as a an area in which rapid improvement was a necessary condition for the achievement of large-scale results. It was countered that while short-term actions were indeed necessary, it is important to recognize that some capacity-particularly involving procurementalready exists within ministries and needs to be built-òn.

One speaker argued that while speed of implementation is important, there is a need to study procurement options (i.e., design and supervise vs. design and build) based on experience with existing projects. Such a study would in form the types of contracts tofuse for new projects and result in greater success. Crown Agents agreed to conduct such a study and share results. Several attendees listed other issues to consider while determining which options to use: first, that the hiring of mänagement firms may create conflicts since they may become privy to confidential information about competitors-and so this risk needs to be addressed carefully during the preparation of TOR. Another issue to consider is that some functions (e.g., IT) span ministries, and it might be more efficient to address these functions in a unified manner.

A number of more general comments were also made. One workshop attendee asserted that it is crucial that capacity-building not be forgotten as a result of day-to-day pressures to focus on implementation. Another argued similarly that as there is no substitution for hands-on experience, it is imperative that consultants seek to involve agency staff in all aspects of their work. A third suggested that donors (particularly Development Banks) need to relax procurement requirements for the hiring of consultants, as they are currently too cumbersome and slow. Finally, a speaker asserted that equal attention should be paid to all ministries responsible for large investment programs, and to all provinces of the country. 


\title{
Next Steps
}

His Excellency Minister of Communication Eng. Masoom Stanekzai outlined the next steps that should be taken by the participating ministries to ensure timely implementation of capacity-building measures. First, each ministry would undertake a rapid assessment of its individual capacity-building plans-mapping their intention to draw from the menu of capacity-building options and assessing how best to apply PRR to support the effective use of their chosen strategy. H.E. Minister Stanekzai then stated that he and H.E. Minister Ghani would convene a meeting of all the relevant ministers the following week at which they would discuss how to move forward.

Immediate actions are necessary and crucial-each ministry should produce detailed plans and Terms of Reference within a week or two.

\section{Priority Restructuring and Reform (PRR)}

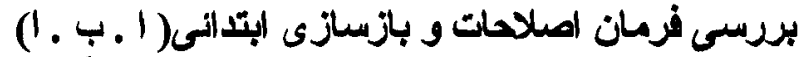

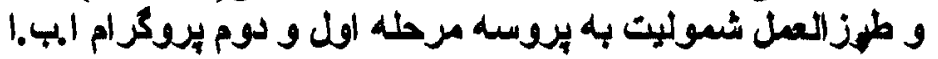

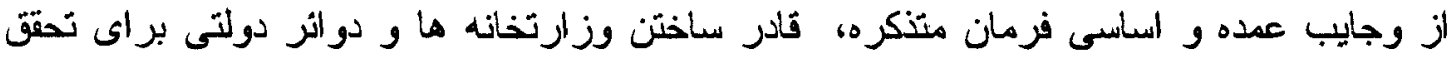

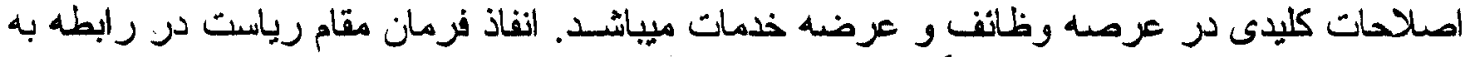

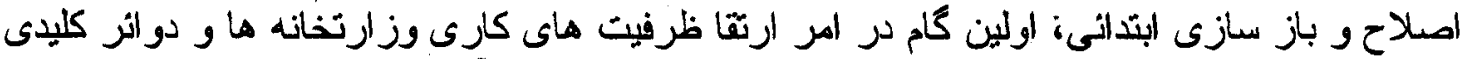

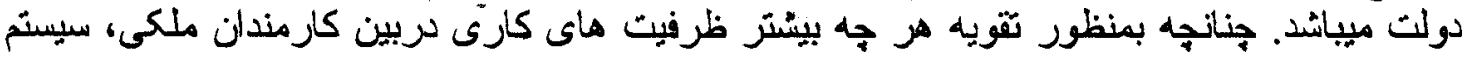

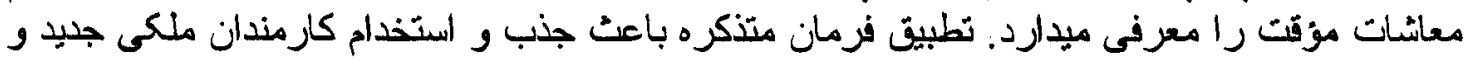

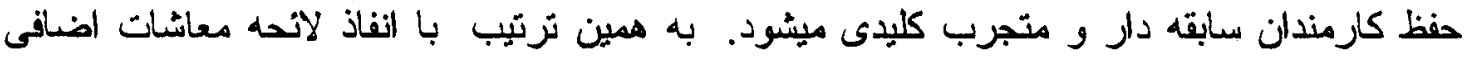

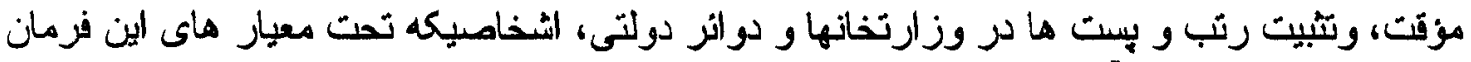

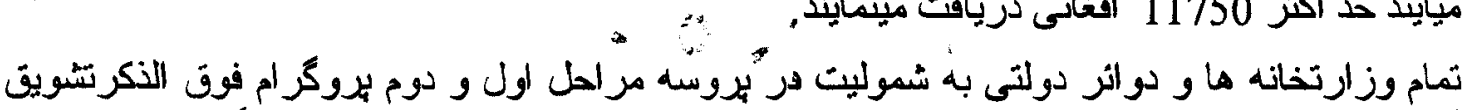

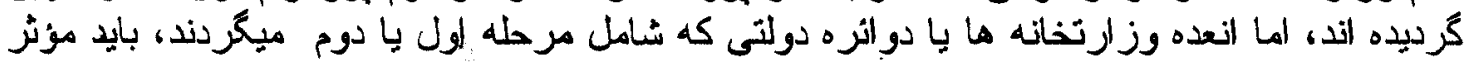

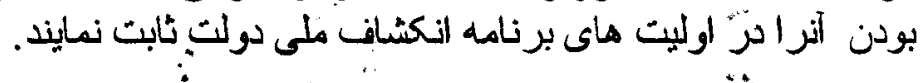

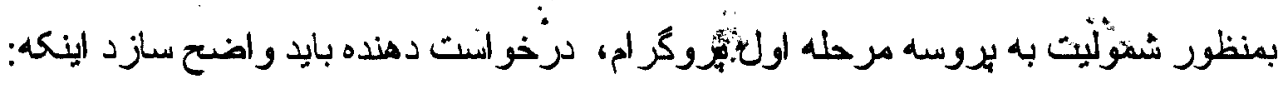

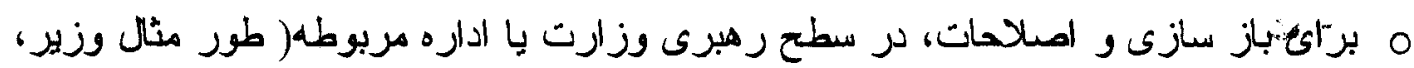

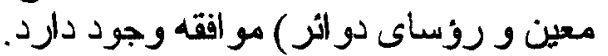

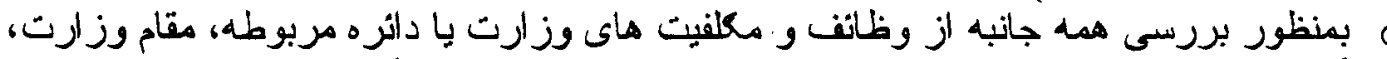

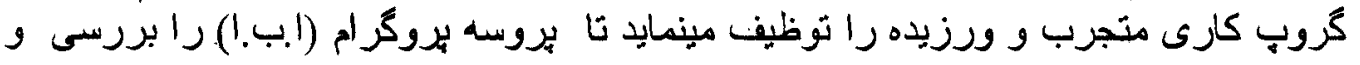

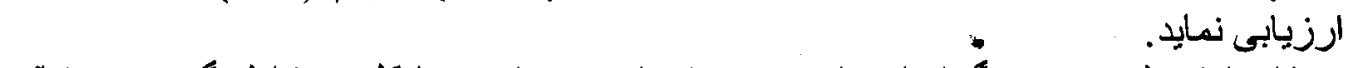

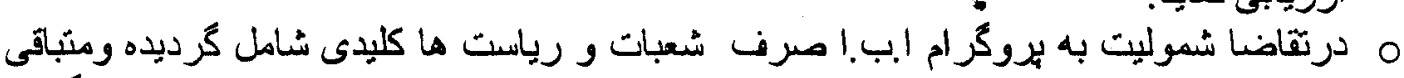

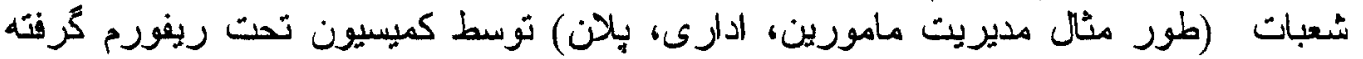

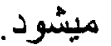

$$
\begin{aligned}
& \text { م در بلان هاى طر ح شده مؤئريت و صرفه جونى، در نظر كرفنته شود. }
\end{aligned}
$$




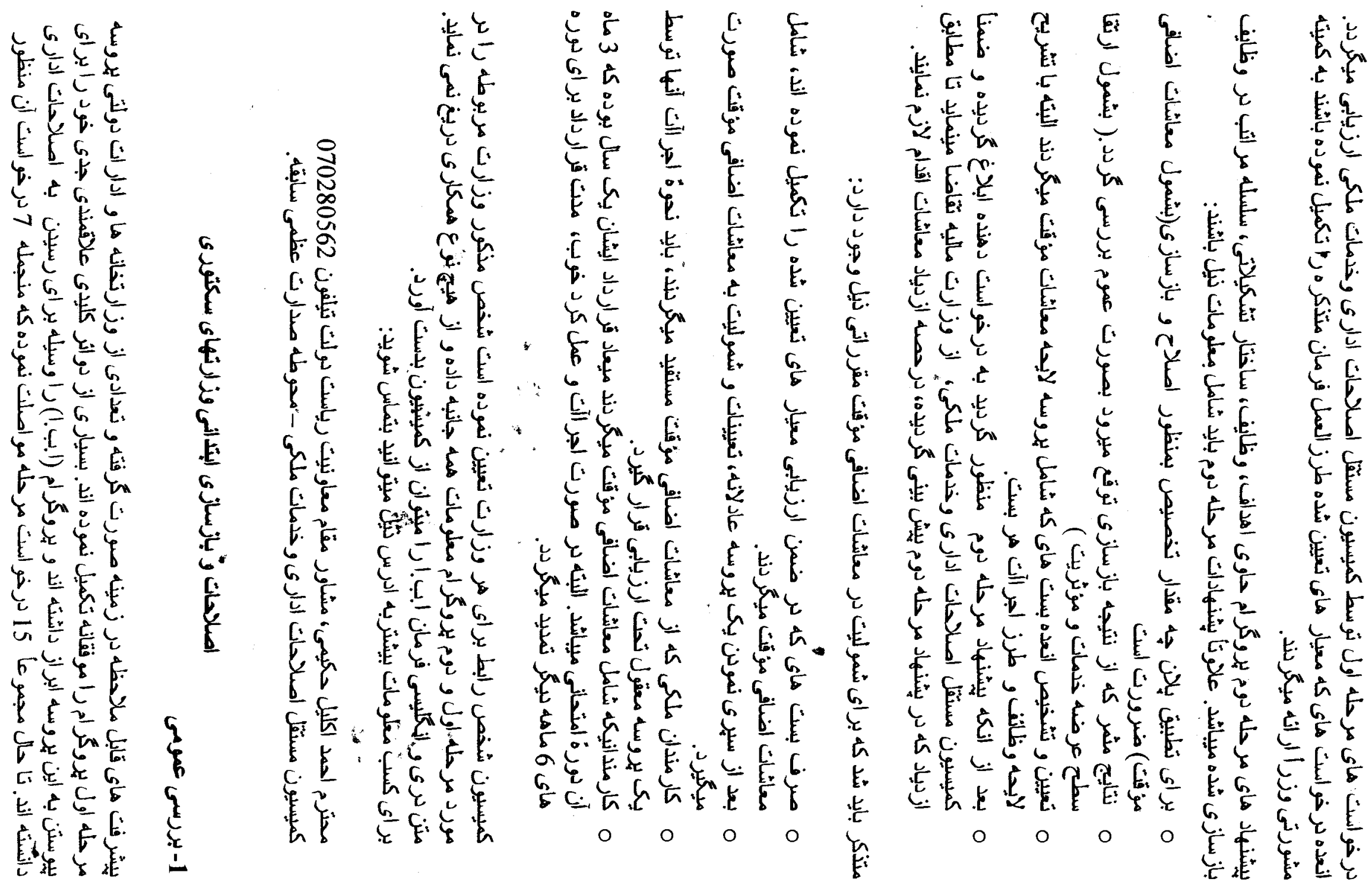



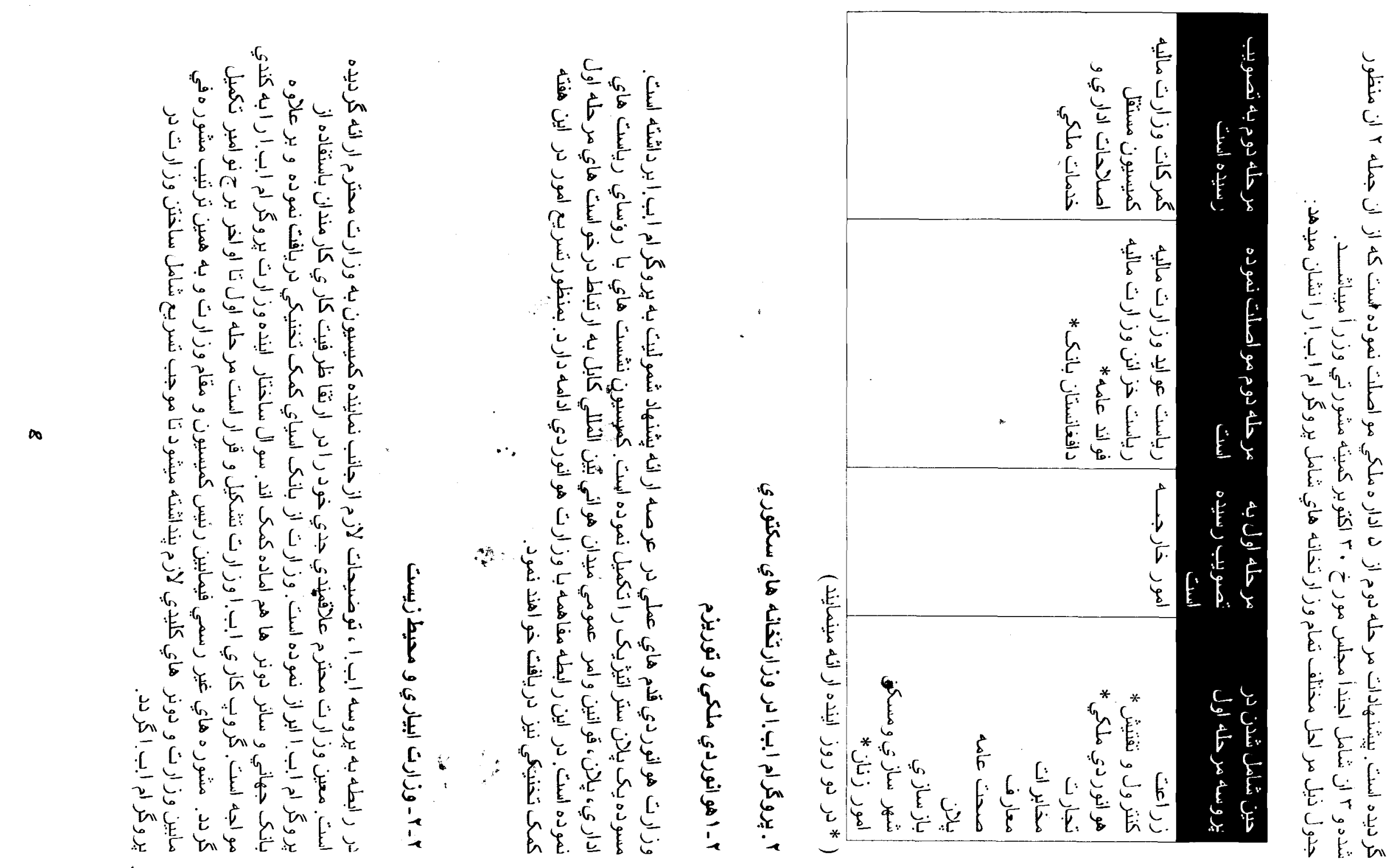


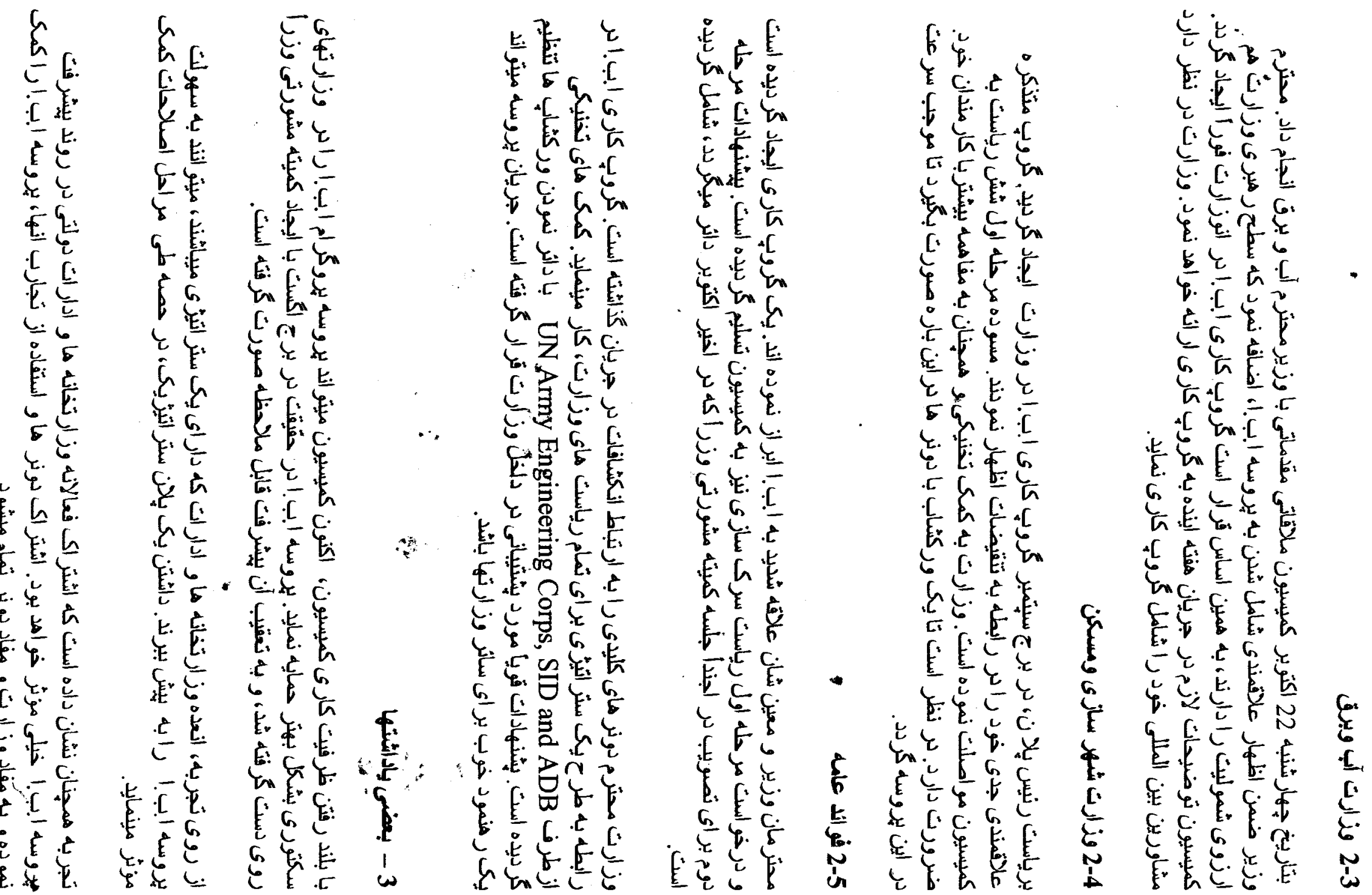




\section{Overview of the PRR Decree and PRR Application Procedures}

The primary objective of the PRR Decree is to enable government ministries, agencies and departments to carry out key reforms that are central to improving the delivery of priority functions and services. The Decree enables ministries and agencies to make an initial step towards capacity building by introducing an interim pay and grading system which will aid the recruitment and retention of key civil servants. Accordingly, under the provisions of the decree, approved posts in ministries/agencies granted PRR status are entitled to receive an Interim Additional Allowance ('IAA') which raises the maximum total salary level to Afg 11,750 per month.

All ministries and agencies are encouraged to apply for a PRR status. The two-stage selection process is robust and applicants will need to demonstrate that reforms are essential to meeting high priority national development objectives.

In the first stage of the application process the applicant must ensure:

- There is a commitment to restructuring and reform at the highest levels of management (i.e., Minister, Deputy Ministers and Department Heads).

- A thorough review of the ministry's/agency's functions has been conducted by a suitably skilled team of people appointed by the Minister/Head of Agency to lead the PRR initiative on his/her behalf.

- Requests for PRR status are limited to departments within the ministry/agency which support priority tasks and implement and deliver priority policies and services. Note that PRR applications from departments which perform functions which are common across ministries/agencies (e.g., correspondence, personnel, planning etc.) or functions which are not essential to achieving national development objectives will not be approved.

- There are credible plans for rationalising the activities of the ministry/agency to enhance efficiency and cost-effectiveness.

Stage 1 applications are reviewed by the Independent Administrative Reform and Civil Service Commission ('IARCSC'). Applications that meet the requirements of the Decree and related procedures are submitted to the Ministerial Advisory Committee ('MAC') for approval.

The second stage of the process requires the ministry/agency to provide a detailed account of the purpose, objectives, structure, staffing levels and lines of accountability of the restructured function. This must include:

- A robust implementation plan which includes a zealistic assessment of the costs of restructuring (including IAAs, equipment costs and technical assistance) and credible plans for obtaining the necessary funding.

- A thorough analysis of the expected benefits of restructuring, including enhanced service delivery and efficiency.

- Identification of the posts recommended for transfer to the IAA scale, accompanied by job descriptions, outputs and performance assessment criteria for each post.

Once a stage 2 application has been approved, the applicant department is awarded PRR status. The IARCSC will then arrange for the Ministry of Finance to increase the department's salary budget in accordance with the increases specified in the application.

Note that there are strict rules regarding qualification for lAAs:

- Only posts specified in a successful PRR application will be transferred to the IAA scale.

- The appointment to IAA posts must be through a fair and merit-based selection process.

- There must be a process for assessing the perfornance of civil servants receiving IAAs. 
- Employees appointed IAA posts will be placed on a fixed-term l-year contract with an initial 3-month probationary period. Subject to satisfactory performance, the contract may be renewed for further 6 -month periods.

Dari and English versions of the PRR Decree are available from the IARCSC. The IARCSC also has a dedicated contact person for each ministry/agency. The contact person will provide briefings and assist the ministry/agency in developing their applications for PRR status.

For further information, contact:

Mr Eklil Hakimi

Advisor to Vice President and Chairman of IARCSC

Eklil.hakimi@afghanistangov.org

phone: $070-280562$

Independent Administrative Reform and Civil Service Commission

Prime Ministry Compound

\section{Priority Reform and Restructuring in Sector Ministries}

Considerable progress has been made and a number of departments and agencies have completed the first stage of their application process. Most key departments and agencies have expressed interest in using the PRR vehicle to pursue administrative reforms. To date, fifteen Stage 1 applications have been received, of which seven have been approved. Three Stage 2 applications have been received, of which two have been approved and one will be considered at the next Ministerial Advisory Committee meeting on October 30th. The following table summarises the current status of all ministries/agencies which have commenced the PRR application process:

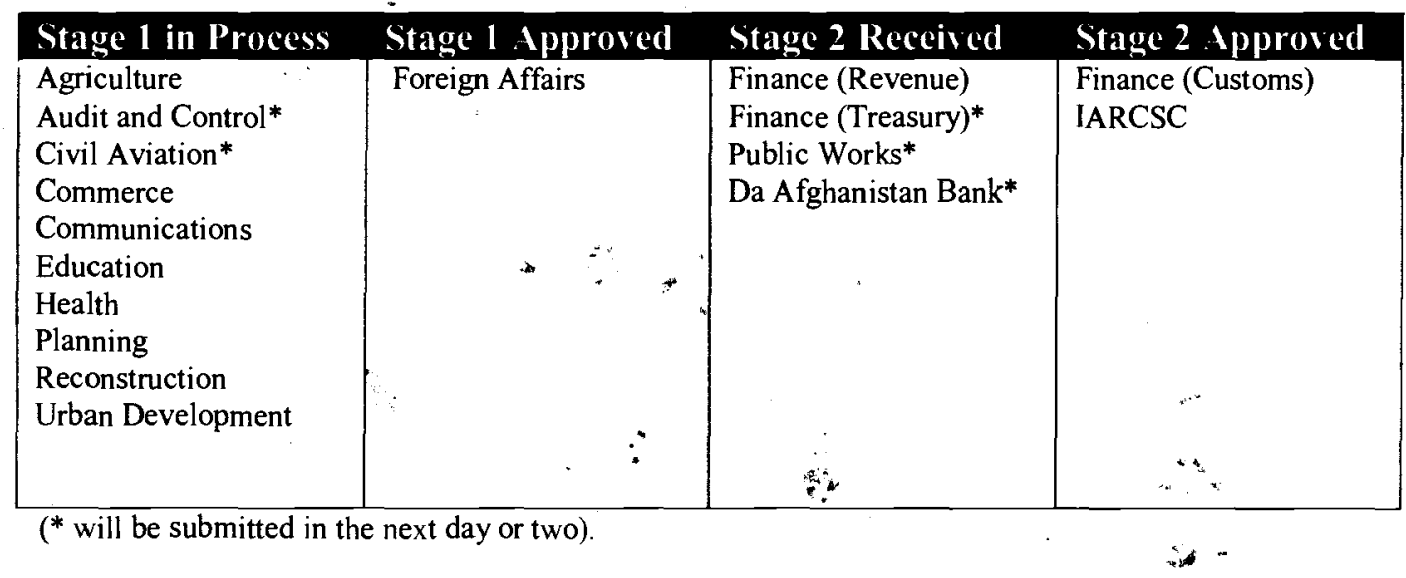

\section{Observations}

.The IARCSC now has improved capacity to support the PRR process in these complex sector ministries. The PRR process really took off only in August when the MAC was constituted. Progress since then is impressive.

From experience, it is clear that ministries and agencies which have a strategic vision are more readily able to engage with the PRR process. A strategic plan helps to prioritise and sequence reform steps.

It is also good practice to have Ministers actively participate in PRR teams. The PRR process is far smoother when key donors are involved in the PRR process. This is beneficial not only to the ministry but also to the donors themselves. 


\section{Preliminary Restructuring and Capacity-Building Plans}

\section{Ministry of Civil Aviation and Tourism}

The Ministry of Civil Aviation (MCAT) has not yet decided to seek Priority Reform and Restructuring (PRR) status for any of its departments, in terms of the Decree on Priority Reform and Restructuring within Ministries and Government Agencies (PRR-decree).

The MCAT has, however, prepared a preliminary strategy for how to reform, restructure and strengthen the Ministry. The MCAT's strategy, in a document entitled Reform, Restructuring and Strengthening of the MCAT (draft), has three components:

- A proposal for how the MCAT should be organised during the process of its reform and restructuring as well as for how it should be organised at the end of this process.

- An approach for how to drive the reform and restructuring process which relies heavily on the PRR-decree.

- The provision of capacity to manage the reform and restructuring process.

It is assumed that the strategy for Reform, Restructuring and Strengthening of the MCAT will take about four years to implement. At the end of that period it is expected that the MCAT will have a modern organisational structure and the capacity to fulfill its obligations.

The new structure, in terms of the proposed strategy, will enable the MCAT to subsequently reform the institutional arrangements in the civil aviation sector further. It is thus envisaged that the flight safety operations, air transport sections to be reformed as regulatory body, and the other sections such as ATC, airports and all service ptovider departments may in the future be as agencies or enterprises in suitable time.

To implement the strategy, MCAT will require substantial technical assistance. The first step is the recruitment of advisors to the proposed new Capacity Building Unit (CBU) in the MCAT. These advisory services will also be required to assist the MCAT implement upcoming investment projects.

\section{Need for Technical Assistance Support}

\section{Identification, preparation and supervision of capital works projects}

The following projects are being or will have to be implemented by the MCAT, for which the captioned consultancy service can normally be assumed to be available.

- The rehabilitation and upgrading of Kabul International Airport financed under the World Bank's Emergency Transport and Rehabilitation Project.

- A technical assistance project sponsored by the $\mathrm{ADB}$ for preparing a master plan for rehabilitating the regional airports.

- The ADB sponsored TA is expected to result in two loans for regional airport rehabilitation, one to be approved in 2004 in an amount of USD 40 million and another in 2005 for USD 30 million.

- Other TA projects recommended in the Transport Sector Review, including for preparing for the upgrading of the Air Traffic Management system. 
At present, MCAT has limited capacity for serving as the client for and therefore actually managing these projects. As concerns the World Bank-financed rehabilitation of Kabul lntemational Airport.

techinical assistance available to the MCAT at the present time.

\section{Reform, restructuring and strengthening of MCAT}

The needs of the MCAT at present are primarily for consulting services to:

- Make up the core of the Capacity Building Unit (CBL)

- Provide Project Management Support for the implementation of donor funded capital and technical assistance projects

The envisaged consulting team (CBU Consulting Team) is proposed to comprise the following:

- An expert on a full time basis for a period of three years, with a background in the management of a ministry of civil aviation or civil aviation authority.

- An expert on a full time basis for a three year period to be overall responsible for organising training programmes, to manage other TA consulting contracts, ard to manage the other experts to be provided by the CBU Consulting Team. To train counterparts at least two Afghans in each field and areas of their work to enable those Afghans to ultimately take over the job at the end of the project.

- Experts on a part time basis to partly work in their home office; partly in Afghanistan and in the following areas (i) airport terminals and infrastructure; (ii) ATM; (iii) CNS; and (iv) aviation safety.

The outline Terms of Reference for the Team is overleaf. The estimated input is of the order 120 manmonths at a total cost of some USD 3 million. Once this program has been initiated, there will be further substantial needs for technical assistance to actually reform, restructure and strengthen MCAT.

\section{Draft Terms of Reference Ministry of Civil Aviation and Tourism}

\begin{tabular}{|l|l|}
\hline Implementing Agency: & Ministry of Civil Aviation \& Tourism \\
\hline Duration: & Three years \\
\hline Year of Commencement: & Immediate \\
\hline Objectives: & $\begin{array}{l}\text { Assist MCAT } \\
\text { 1. to reform, restructure and strengthen MCAT through its } \\
\text { Capacity Building Unit (CBU) } \\
\text { 2. to manage donor financed capital and technical assistance } \\
\text { projects. }\end{array}$ \\
\hline Tasks: & $\begin{array}{l}\text { 1. Reform and Restructuring } \\
1.1 \text { Assist with applications for PRR-status } \\
1.2 \text { Prepare detailed strategy for Reform and Restructuring } \\
1.3 \text { Prepare preliminary designs for all the outputs of the strategy. } \\
1.4 \text { Design Technical Assistance (TA) to assist with the final }\end{array}$ \\
\hline
\end{tabular}




\begin{tabular}{|l|l|}
\hline design and implementation of the outputs. \\
1.5 Manage all TA contracts for which MCAT is the Executing \\
Agency. \\
1.6 Coordinate TA activities and donor support to the CBD. \\
1.7 Serve as main advisor to the Minister on all reform and \\
restructuring activities. \\
1.8 Overall responsibility for the planning and execution of \\
training programs \\
$\begin{array}{l}1.9 \text { Assist with the mobilisation of funds for TA. } \\
\text { 2. Project Management Support: } \\
1.1 \text { Assist with the implementation of TA projects } \\
\text { for which MCAT is not executing agency } \\
1.2 \text { Review of feasibility and similar studies } \\
1.3 \text { Review of preparation of procurement documents for capital } \\
\text { works } \\
1.4 \text { Oversight of the selection of contractors for project } \\
\text { implementation } \\
1.5 \text { Oversight of contract supervision, monitoring, including } \\
\text { financial control and technical supervision of capital works. }\end{array}$ \\
\hline \begin{tabular}{l} 
USD 3 million \\
\hline Estimated Cost:
\end{tabular}
\end{tabular}

\section{Ministry of Public Works}

The Ministry of Public Works (MPW) has decided to seek Priority Reform and Restructuring (PRR) status for one of its departments, in terms of the Decree on Priority Reform and Restructuring within Ministries and Government Agencies (PRR-decree). A Stage one application, for PRR status to be awarded to the Department of Maintenance, was submitted to the Independent Administrative Reform and Civil Service Commission (IARCSC) on 3 September 2003.

At a meeting on 8 September 2003 between H.E. the Minister of Public Works, AACA, the World Bank and advisors to the MPW, the challenges faced by the MPW in achieving PRR status, in particular, and accomplishing reform and restructuring, in general, was discussed. It was resolved at this meeting that a strategy for comprehensive reform and restructuring of the MPW was to be prepared. Subsequently, in response to the requirtments laid.down by the Ministerial Advisory Committee of the Independent Administrative Reform and submission of a Stage 2 application for PRR-status to be awarded to the Department of Maintenance, it was decided that such a strategy should form part of this application.

On 21 October 2003, MPW submitted a Stage 2 application to the IARCSC, together with the proposed strategy referred to as the Program for Reform and Restructuring of the Ministry of Public Works.

The MPW Program for Reform and Restructuring has three components:

- A proposal for how the MPW should be organised during the process of its reform and restructuring as well as for how it should be organised at the end of this process.

- An approach for how to drive the reform and restructuring process which relies heavily on the PRR-decree.

- The provision of capacity to manage the reform and restructuring process. 
It is assumed that the Program for Reform and Restructuring will take about five years to implement. At the end of that period it is expected that the MPW will have an organisational structure and the capacity to act as a modern manager of roads.

The proposed Program reflects the Government's intention to devolve power to the provinces. It is assumed that decentralization to the provinces can also be effected in about 5 years' time

To implement the Program, MPW will require substantial technical assistance. The first step is the recruitment of advisors to the proposed new Capacity Building Unit (CBU) in the MPW. Further background to this proposal is provided overleaf; outline terms of reference is also attached.

\section{Need for Technical Assistance Support}

\section{Identification, preparation and supervision of capital works projects}

MPW has considerable capacity in this area. The consulting services are normally financed by technical assistance projects or as part of the implementation of donor financed capital works projects. The needs with respect to the primary road network are already met.

As concerns secondary and provincial roads, additional capacity for identification and preparation, and subsequently supervision of implementation is being provided by the Asian"Development Bank (the Master Plan for the Central Region) and the US Government.

\section{Project management support to the MPW}

The MPW is provided with technićal assistance to assist with project management, including:

- One advisor financed by USAID (for all projects).

- One advisor financed by $\mathrm{ADB}$ (for all projects).

- four advisors from the US Army Corps of Engineers on a continuous basis

- Additional advisors for specific projects and provided by the donor financing the project concerned.

These services are viewed as adequate for the present time. There is a need to coordinate this support, which is expected to be done by way of the Capacity Building Unit, referred to below.

\section{Reform, restructuring and strengthening of MPW}

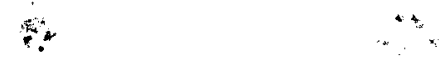

The needs of the MPW at present are primarily to muster the capacity for implementing its Program for Reform and Restructuring. This is proposed to be done by the provision of advisors to the new Capacity Building Unit. The initial need in this area is envisaged to comprise three experts on a full time-basis, over, initially, a three-year period, and costing in approximate terms $\$ 2.3$ million. It is highly desirable that at least one of these experts is of Afghan decent and fluent in at least Dari, and preferably also Pashto. These experts would have the following competencies:

1. The management, organization and operations of a roads department/authority

2. Systems, procedures and management information systems used by a roads department/authority

3. Development and implementation of training programs, as well as recruitment under and management of donor financed TA projects 
Once this program has been initiated, there will be further substantial needs for Technical Assistance to actually reform, restructure and strengthen MPW. It is understood that the US Army Corps of Engineers will provide the required assistance both to the $\mathrm{CBU}$ as well as for further TA.

\section{Draft Terms of Reference Ministry of Public Works}

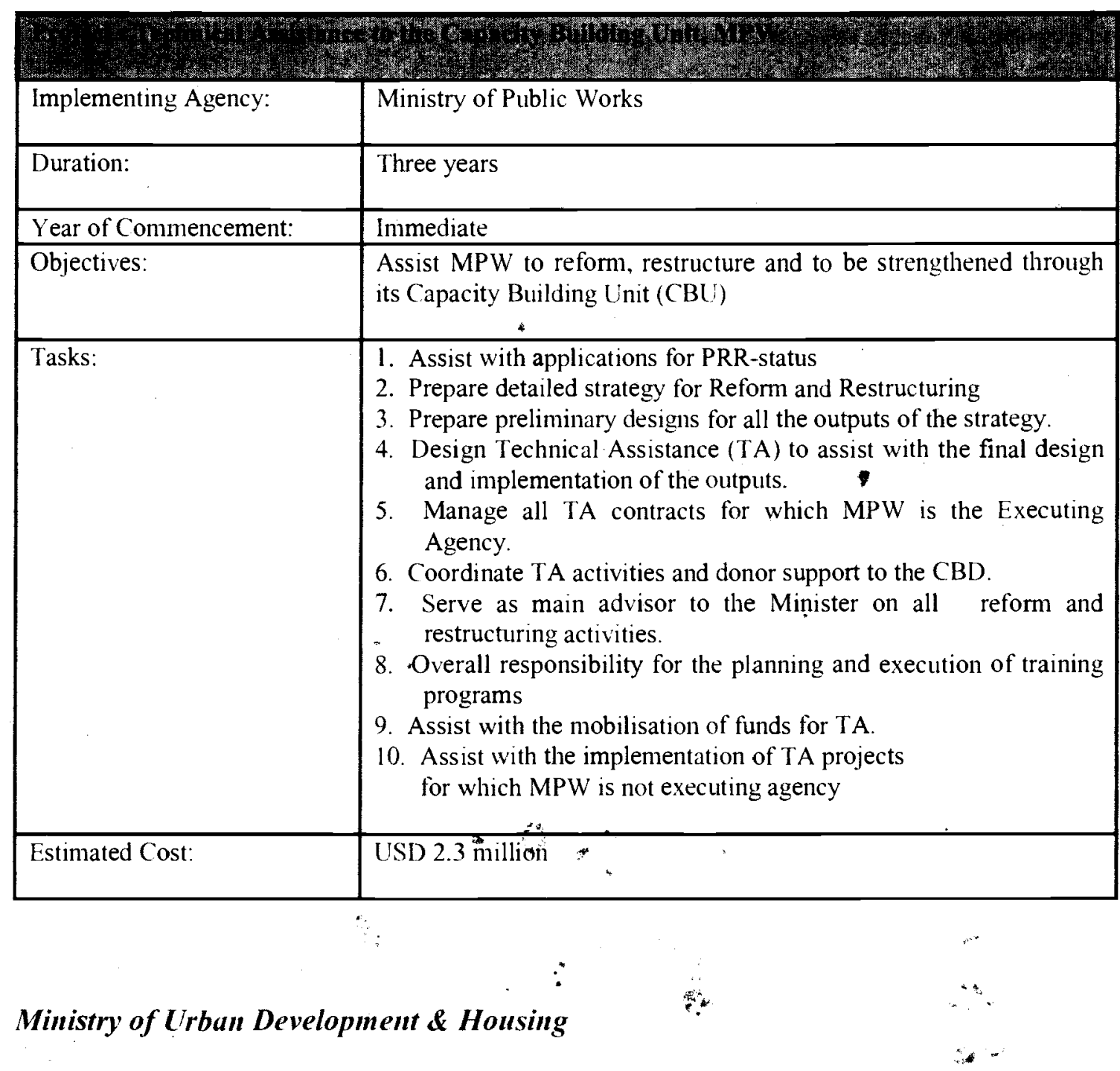

Here is a summary of the status of existing plans to strengthen the capacity of the Ministry of I rban Development and Housing. During the last mission to Kabul (Sep 21 - Oct 9), the urban task team met with the Deputy Minister and reviewed the instruments ar ailable to the Ministry which could be used to increase its capacity to discharge its functions. The options discussed were:

\section{General Assistance}

I. Appointment of lead urban specialist(s) (funded by ARTF) as the senior advisor to the Minister and his Deputy. We reviewed several CV's with DFSU, identified the most promising, and Alex Park undertook to interview the three top candidates in the UK during the week of October 13. AACA has requested NO for two of the interviewed candidates. We gave NO to the two with guidance on the main thrust of each advisor s task: one for policy development and the other for project development. 
The expected cost of each advisor for two years is about $\$ 240,000$ per annum, to be funded from the ARTF. The policy advisor is expected to give short-term inputs during the two year period of service.

Terms of Reference: Lead Urban Specialist (Policy)

$\mathrm{He}$ /she will assist the MUDH in identifying key urgent urban policy issues for attention, and also design and manage the policy agenda for the MUDH. Expected policy issues of concern include: (i) housing policy, (ii) new settlements policy, (iii) planning policy, (iv) service delivery to informal settlements, (v) financing of urban areas, (vii) administration of urban areas, (viii) infrastructure development in urban areas, (ix) land tenure. (Note that several of these do NOT come directly under MUDH, but are key to the successful management of urban areas).

Key Deliverables include: Identification of Key Urgent Urban Policy Issues; design of Urban Policy Agenda; Writing of TORs for specialist input into Policy Agenda; assisting MUDH in the coordination of the Urban Policy Agenda

Terms of Reference: Lead Urban Specialist (Projects)

$\mathrm{He}$ /she will assist the MUDH in the development of a practical programme of projects, liaison with donors on such a program and identification of key issues that require attention for the implementation of projects; providing on-the-job training of Afghan counterparts in project design and implementation.

Key Deliverables include: Identification of key projects; writing of TORs for specialist input; assistance on Project Management and Procurement

II. Appointment of a management firm with primary responsibility to: i) identify priority urban infrastructure investments, ii) provide TA to develop projects or engage other consultants to do the same under their direction, and iii) implement a capacity building program to create a fully functioning project management unit for the Ministry. Draft TORs have been produced without reference to any particular consultant firm. (Draft TORs attached). MUDH supports the concept as long as. the Ministry is firmly in control of the consultants and the consultants do not get into policy work, which may more properly fall to the lead urban specialist. The proposal includes a team of 5 technical specialists for a period of three years at a total cost of $\$ 4.5$ million. Possible sources of funds include ARTF, Islamic Development Bank, and IDA through the EURP. AACA to prepare RFP.

III. Implementation of the Priority Reform and Restructuring (PRR) program. MUDH does not have the capacity to carry out Stage 1 of the program which is required to gain accéss to the second stage which releases the resources needed for interim additional allowances for deserving workers. Launched by the Lead Urban Specialist (Policy) with assistance of World Bank Country Office.

IV. UN-HABITAT appointed staff. Two JPOs (Junior Professional Officers) will be appointed to work with MUDH. The Italians are funding a planner and water supply specialist. SIDA is funding a physical planner. They will both be based in the Ministry. I is proposed that the latter JPO be deployed as an assistant to the Deputy Minister with a focus on office management.

\section{Project Specific Assistance}

I. Italian Assistance $(\mathbf{\$ 3 0 0 , 0 0 0 )}$. MUDH is currently the recipient of technical assistance from the Government of Italy. The program is not functioning well, as a recently deployed planner has left the country for unexplained reasons. This assistance needs to be reviewed and perhaps redesigned to perform better. 
II. Individual Returned Afghan Planning Specialists. MUDH has engaged a number of Afghan planners who have returned to Kabul in the last several months. Two planners have been contracted under the PCF but owing to delays in the payment of salaries have left the Ministry. One planner has been financed by CIM (Germany). All three were engaged in the preparation of revised plans for major towns, a priority task. Expediting the payment, of salaries out of the PCF might encourage the return of the two planners to the Ministry.

III. PADCO assistance $(\mathbf{\$ 2 5 0 , 0 0 0 )}$. A proposal to initiate the preparation of a concept plan for the City of Kabul is being processed through the DFSU. The objective of the project is to gather information and carry out technical studies and related efforts to strengthen the institutional framework for city planning. Data collection by MUDH staff has started. Once approved by DFSU for funding, the program is designed to be completed in three months. DFSU should expedite the approval of the project in order to capitalize on the pro bono work done by PADCO to date and to continue offering practical experience to MUDH staff in contemporary methods of town planning

IV. Emergency Urban Reconstruction Project. ${ }^{2}$ Under EURP there are proposed to be two capacity building efforts directed towards MUDH. The first will be complementary to the activities of the appointed consulting firm in that TA will be provided by a project management specialist, an engineer, a financial management specialist and a procurement specialist (possibly assisted by a procurement analyst) to manage the implementation of the project. The second $\mathrm{CB}$ effort will be provided under the EURP component to prepare a revised structure plan for Kabul, incorporating the PADCO work. This will address MUDH's urgent plea for more town planning capacity in MUDH. The Ministry will push for the replanning of other towns. TORs for these individuals will be prepared as part of final project preparation during the next 8 weeks.

\section{Future Needs}

The investment agenda and the policy agenda that will be developed over the next few years through the mechanisms mentioned. Some capacity building will also occur. However, to successfully implement the investment agenda and the policy changes will require changes in the MUDH in the medium term. In this way, an institutional restructuring of the MUDH will have to occur AFTER the PRR and the policy discussions to reflect the needed tasks of the Ministry. Currently, the structure MUDH does not reflect the listed tasks of that Ministo. Needed new skills for the MUDH will also emerge: MUDH currently contains largely structural/civil engineers. There is a need for a broader range of skills in order for MUDH to carry out it remit for the urban sector.

\section{Draft Terms of Reference - Ministry of Urban Development and Housing}

\section{Background}

1. The urban centers of Afghanistan suffered extensive physical damage during the long conflict, which also affected official and private investments in housing, urban services, and commercial development. Given that urban populations continued to grow, partly as a result of displacement, the pattern of under-investment in basic services has resulted in deteriorated urban living conditions, with ever-greater numbers of people reliant on short-term humanitarian support. Apart from extensive investments by individual householders in self-built traditional housing, the role of the private sector in housing or commercial development has been negligible. Given the political turmoil that prevailed, the regulatory framework for urban development atrophied, or was simply ignored.

2. Since early 2002 the major urban centers have been the focus of significant return of Afghan refugees and exiles, which has put huge pressure on degraded services and on the institutions responsible for managing urban recovery. While the pace of some aspects of private investment in urban areas has visibly grown in the past year, this growth can only be sustained if matching 
investments are made in the rehabilitation or development of basic services, whose coverage continues to fall well below the actual demand. Even with additional resources for physical rehabilitation being made available, there is a need for simultaneous investment in institutional strengthening and reform to realize the potential of major urban projects. A number of initiatives aimed at emergency rehabilitation of power and water, as well as priority road repairs, are under way. It is important to cøordinate with the work in progress in order to ensure that the action of specific agencies reflect official priorities, and are sustainable. Given the potential importance of the urban centers in the process of economic recovery, failure to make additional strategic investments puts the wider process of reconstruction in the country in jeopardy.

3. It is in this context that the Afghanistan Transitional Administration aims to seek support for priority investments in urban rehabilitation, in order to boost the economic recovery of urban centers in the country. The initial focus for these investments will be on specific projects which aim to develop basic services (water supply, sanitation/drainage and electricity) and improve public access, as well as make available affordable residential and commercial land, while taking steps to protect the urban environment. While there are a number of line ministries involved in attempts to facilitate urban development, the principal counterpart for the consultants will be the Ministry of Urban Development \& Housing, whose official responsibilities within the administration include:

- Providing physical planning services and advice for all municipalities, including Kabul Municipality and some 60 other urban areas;

- Providing project designs for housing development, inffastructure development, implementation and management support for municipalities and other local administrations;

- Promulgating housing, building and planning standards

- Planning, design and supervision of the Government building program; and

- The formulation and implementation of national housing policies.

\section{Purpose}

4. MUDH currently has limited professional capacity to discharge its responsibilities. In the light of the need for strategic investments to be made in urban areas, the services of a consulting firm are required in order to provide support to the Ministry and other stakeholders in discharging several key responsibilities within its wider mandate. This work will be performed according to international standards, under the direction and reporting to the Minister of Urban Development and Housing, in consultation with other Ministries as applicable.

\section{Scope of Work}

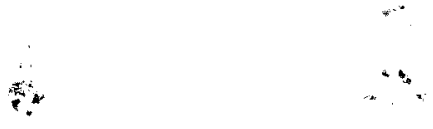

5. Given the scale and complexity of the needs, it is envisaged that this consultancy will call or three outputs, the first of which will entail a situation analysis of the current processes whereby investments are made in a variety of urban sub-sectors and the identification of priority strategic infrastructure projects, the second will provide technical assistance for project planning, design and management, and the third will be a capacity building program in MUDH and other agencies in support of a range of fast-track urban development initiatives.

Output One: Situation Analysis and Priority Actions/Investments. It is proposed that the initial focus of the consultancy will be on diagnosing the constraints and opportunities that exist with regard to public or private investments in urban development, namely:

- development of serviced land for residential, commercial and industrial use;

- provision of safe water, environmental sanitation and drainage;

- provision of adequate vehicular and pedestrian access; and 
- protection of the urban, environment.

6. The consultants will be required to undertake a situation analysis of the current processes whereby investments are made in each of the above, with diagnosis of the major constraints to further development, and prioritized recommendations for action and investments that emerge from this analysis. Each of the four areas above should be assessed with regard to the following constraints and/or opportunities, and address the specific cultural and Islamic traditions of the country:

- physical - the extent and scope of ongoing investments/activities (private, NGO or other), the availability of resources (land, funding, plant/equipment etc), the scale of current needs/demand, and the potential environmental implications;

- institutional - the responsibilities, procedures and relationships that prevail between ATA institutions in support of urban development, how these do or don't work, and priority areas for possible facilitation/reform; and

- legal - the various regulatory frameworks (zoning, construction and service standards/controls, ownership laws, taxation and operational costs) that prevail with regard to the respective areas of urban development, and how they do/not facilitate investments.

7. The situation analysis should draw upon baseline information and consultations with key Ministries with responsibilities for urban management and redevelopment (including Urban Development \& Housing, Public Works, Reconstruction, Power and Water, Justice, Commerce and the respective municipalities) as well as external agencies (UN, NGO and donors including European Commission, Government of Japan, Government of Germany) who are active in urban rehabilitation. These consultations should not duplicate, but draw on ongoing and existing studies (World Bank, $\mathrm{ADB}, \mathrm{UN}$ ) that have been undertaken on aspects of urban rehabilitation and management

8. The situation analysis, together with recommendations for reforms, the short, medium and long term urban reconstruction strategies, and key investments will be presented in a report to the MUDH within a period of six weeks of the initiation of the consultancy. The recommendations, which will have been discussed with the concerned institution/s, will address immediate high priority reform actions and a medium to long term strategy for effective urban development and management, as per the areas of focus outlined above.

9. Following the findings of the situation analysis, a series of priority urban development projects will be identified from among the list provided by the consultants by the MUDH, to be implemented by MUDH or the identified Ministry, department or agency. Where identified projects are not included in the National Development Budget, these will be presented to the Government for consideration.

Output Two: Project management services. The consultant will be responsible, on behalf of the MUDH, for providing project management services for the implementation of approved priority investments, according to identified International Standards. The immediate focus of Stage 2 will be projects that emerge from the five areas identified in the situation analysis. These consulting services will include, but not be limited to:

- preparation of a project management and supervision manual which should cover all stages of the implementation process, and specify responsibilities

- initial project assessments and preparation of project concept notes;

- selection of consultants for the preparation of priority urban projects

- review of feasibility studies and project designs for projects under preparation

- review of preparation of procurement documents;

- oversight of the selection of contractors for project implementation

- oversight of contract supervision, monitoring, including financial control and technical supervision of construction (where not supervised by the consultant) 
10. An integral part of project management will be the strengthening of strategic capacity within the MUDH, to which the third output would be devoted.

Output Three: Capacity building program. The objective of the program will be to produce a fully function project management unit in the Ministry of Urban Development and Housing within two years. The Consultant will prepare a program of capacity building activities over and above the knowledge and skill transfer achieved on the job. Such activities should include short training courses in project management tools and attachments to well functioning project management units abroad. The program will be produced within 2 months of the start of the consultancy for submission to MUHD for review and approval.

\section{Reporting}

11. Implementation of recommendations proposed under Output One which have been accepted by MUDH will be managed by the consultants, in close collaboration with the institutions concerned, and at least monthly updates will be provided to the MUDH on the status of implementation in relation to the specified time-frame.

12. Progress reports related to Output Two and Output Three will be produced on at least quarterly basis by the consultants in an agreed reporting format, including inputs from all participating agencies or institutions. An important feature of the monitoring process will be to provide early feedback of unexpected delays or obstacles and proposed remedial action.

13. On a semi-annual basis a consolidated report will be presented to MUDH covering all three Output requirements. The report would review, in a format agreed with the MUDH, progress, achievements or constraints - related to the prioritized reform agenda made in the situation analysis/diagnosis, with proposed measures to address identified delays or shortcomings. A second section of the report will identify progress, achievements or obstacles and further recommendations made to address identified deficiencies with the implementation of the short, medium and long term urban reconstruction strategies; a section of the report will identify progress of each project under the responsibility of the consultant, reporting on project management at key milestones, or significant problems and remedial actions taken. A final section will report on the progress of the capacity building strategy.

\section{Skills Required}

14. While left to the Consultant to determine the skills rêquired for the assignment based on their findings under Output One, it is expected that the following technical personnel will bsrequired:

- Team Leader with background in urban planning or civil engineering and a concentration in program development and project management;

- Technical manager with experience in project level design work in urban infrastructure

- Procurement specialist

- Financial management specialist

- Civil engineer with 10 years experience in project supervision in South Asia.

\section{Technical Equipment}

15. The consultant should provide all necessary vehicles and office equipment required to pertom the duties of the assignment. This may include four-wheel drive vehicles, computers, scanness: printers, fax machines, cell-phones and associated consumable materials. 


\section{Support Provided by MUDH}

16. MUDH will provide office space and basic office furniture, secretarial support, drivers and technical counterparts to form part of the consultant team.

\section{Contract Limitations}

17. To avoid conflicts of interest, under no circumstances, the consultant shall compete or participate as consultants in any of the projects procured by them on behalf of the MUDH.

\section{Ministry of Water and Power}

Existing Technical Assistance to Support Implementation Capacity of the Ministry

- Two resident policy advisors located in the Ministry: one funded by $\mathrm{KfW}$ and another funded by USAID through Bearing Point

- Project Implementation Unit funded by ADB: computers and office equipment provided in addition to training in $\mathrm{ADB}$ procurement and financial management, no expatriate staff,

- GTZ has funded a resident advisor who is working on institution builling of DABM and the Kabul Electricity Distribution department, with priority given to improvements in billing and collection

\section{Plans to Create a Programme Implementation Support Unit (PISU)}

- The Programme Implementation Support Unit will have the following four functions:

- Project Preparation

- Procurement

- Supervision

- IT and Training

- MWP is seeking the services of an engineering consulting firm to field four professionals to form the core of the PISU. These four professionals will be resident in Kabul for an initial period of two years and will report to a Team Leader (which will not be from the consulting firm).

- The Deputy Minister has designated Axel Werner, Advisor, to be the Team Leader for the PISU.

- Each of the expatriate positions will have a twinning arrangement with an Afghan counterpart in order to ensure skills transfer and on-the-job training. Additional staff from the Ministry will be identified for each area as necessary. English language and computer training will also be provided.

- A provisional sum will be included in the consulting firm contract to allow the Ministry to draw on the short term services of specialists, such as environmentalists, hydrologists, etc., as required.

- The ADB-financed Project Implementation Unit will be incorporated into the PISU.

The PISU will focus on the development and implementation of the power investment program. It will not be involved in policy, strategy, sector reform and restructuring and related topics, 


\section{Draft Terms of Reference -, Ministry of Water and Power}

\section{Sector Background}

1. The power sector is one of the least developed ones in Afghanistan, and its inadequate status is . preventing the development of the country. The access ratio is one of the lowest in the world (about 6 $\%$ ), with only 90,000 households connected to the public power grid, of which 70,000 are in the Kabul area. The other provinces have even less access with rural areas being virtually un-served.

2. The existing facilities provide an unreliable service, and in most places for a few hours a day only. Of the about $450 \mathrm{MW}$ installed generating capacity, only $270 \mathrm{MW}$ are available, and most of the units require overhaul or replacement. Distribution systems in the country are dilapidated or nonexistent due to insufficient investment, lack of maintenance, and looting or theft over the past 25 years. The substations and low voltage distribution networks of Kabul and other cities are totally inadequate, overloaded and mostly outdated. Substantial reconstruction and expansion of the distribution systems, based on modern least cost design concepts, will be required.

3. As soon as the distribution systems are reinforced, transmission and generation will become even more inadequate than they are today, due to a rapidly growing load and energy demand. Major rehabilitation and extension programmes have therefore been started, based on funding from multiand bi-lateral organisations. The actually ongoing programmes are aimed at improving the power supply in the short run. For the medium term needs, a major transmission project is being initiated for energy import from the northern neighbours of Afghanistan. Based on the recently produced Power Sector Master Plan, a number of strategic feasibility studies will need to be started soon in order to assess the viability of various power sources.

4. The state utility, Da Afghanistan Breshna Moassasa (DABM), is responsible to the Ministry of Water and Power (MWP) for operation and maintenance of the country's generation, transmission, and distribution assets, as well as for the sale of electricity it produces. DABM has no appropriate governance structure, nor the financial resources to improve the country's electricity services. In spite of being defined in Afghanistan's 1986 Usage of Electricity Act as an autonomous enterprise, DABM depends heavily on government support for its operational and investment funds. Until FY 2003 the salaries of the staff were paid from the MWP budget. With almost 7,000 employees and only 90,000 consumers, DABM is heavily overstaffed. " :

5. The vision of MWP is that by 2010 DABM will "evolve into autonomous, financially viable enterprises providing reliable, low cost electric service to all Afghan citizens in an environmentally responsible manner, consistent with sound busineşs practices". To accomplish this visiog, MWP has planned ambitious projects with the goals of rehabilitating andexpanding the country's transmission and distribution infrastructure, increasing its generation capacity, including through private sector participation, increasing the number of consumers it serves, establishing more appropriäe tariffs, and increasing its revenue through enhanced and effective billing and collection procedures.

6. The physical investment needs for the power sector over the next three years are estimated at about USD $700 \mathrm{~m}$. However, MWP lacks sufficient capacity to implement such a development programme. Many of the sector's staff are close to retirement, and because of the conditions prevailing for the last twenty-five years, most have been unable to remain current with modern methods of management, definition and design, implementation and construction, as well as maintenance in the power sector.

7. The Islamic Transitional State of Afghanistan is keen to scale up the implementing capacity of $^{2}$ key ministries in order to remove one of the main constraints to achieve rapid recovery and development of the country. There is a significant risk that Afghanistan may fail to stabilise and to develop unless a breakthrough is achieved in increasing capacity for preparation and implementation of key development programmes, both in the short and the medium terms. Programme and project 
implementation will also depend on a number of other factors such as security, political stability, good governance, an appropriate policy environment, and availability of donor funds for investment.

8. Therefore, the MWP is seeking the services of an engineering firm to provide technical staff to form the core of its Programme Implementation Support Unit (PISU). The organisation chart of the intended structure is attached.

9. The engineering firm is expected to dispatch four (4) resident professionals, as detailed below, to MWP where they shall work on a continuous basis. In addition, the firm is expected to provide short term experts which may be required from time to time. They will report to the Team Leader who is the already present adviser to the Deputy Minister for Power.

10. The overall goal of the Program Implementation Support Unit is to accelerate implementation of Afghanistan's power sector development program. Each professional shall aim to adequately transfer knowledge and skills to the counterparts by the end of the assignment.

\section{Scope of Work}

11. The professionals fielded by the selected firm would be expected to lead in the following fields of activities:

(i) develop projects from ideas into project concept documents;

(ii) prepare terms of reference and lead in the supervision of the implementation of feasibility studies based, inter alia, on the Power Sector Master Plan, providing comments on behalf of the Ministry;

(iii) manage procurement procedures for the employment of consultants (services) and contractors (goods and works);

(iv) monitor performance and supervise directly consultants, and indirectly contractors through consultants (for some works, directly supervise contractors); and

(v) work closely with MPW counterparts, appropriately transfer knowledge, and build the capacity of the ministry through both on-the-job and other training.

12. While executing the general tasks as described above, the team as a whole shall integrate Afghan counterpart staff assigned by MWP in order provide them with permanent on-the-job training in all activities of the team. Particular training courses in specific matters may complement this capacity building programme. In addition to a solid professignal background, good communication skills and openness for multi-cultural teamwork are therefore required from all team members.

13. The attached organizational chart gives an indication of the tasks to be executed by the professionals. Wherever activities are to be executed by the government's central procurement unit (PU), or outsourced to consultants, the PISU will be responsible for the liaison and coordination.

\section{Timeframe, Skills and Level of Effort}

14. The contract period will be 24 months, with the possibility to renew for another 12 months. The individual professionals are expected to mobilise within two (2) weeks from award of contract. Each professional will be resident in Kabul for the entire 24 month period. Leave outside of Afghanistan may be taken at the firm's discretion, but shall not exceed more than 60 days in total. The professionals should be informed that the work week in Afghanistan is Saturday through Thursday afternoon. 
15. Four professionals to lead the following areas shall be provided:
a) Project Preparation
b) Procurement
c) Supervision
d) Information Technology and Training

16. Positions (a), (b) and (c) will require at least 15 years of professional experience in project preparation and implementation of electric power projects in developing countries, preferably in Central and South Asia. Bidders may combine particular technical experience and skills (generation, transmission, and distribution) with the main categories of team activities (Preparation, Procurement, Supervision) in the persons they propose to assign.

17. Position (d) may be occupied by an IT specialist of non-power background. His duties will include the integration, operation, and maintenance of hardware, software, LANs and individual computers available with the MWP, with the help of local service providers where necessary. In addition, he shall give day-to-day IT training to the Afghan counterparts working with the team.

18. A provisional sum of $[\$ 400,000]$ will be included in the contract ceiling price for the eventuality of the Client to request the firm to provide the short term services of specialists such as environmentalist, social scientist, gas turbine and combined cycle plant specialist, hydrologist, geologist, etc.

19. The bidders shall quote for the permanent employment of two (2) qualified Dari / English translators who shall assist the team in its day-to-day operations, and be expected give English lessons.

\section{Reporting Requirements}

20. Each professional shall provide a brief ( 2 page) monthly report to the Team Leader indicating (i) progress on programme / project preparation and implementation, and (ii) activities and progress in capacity building of the Afghan counterparts. The nature of the work is such that the professional will be expected to respond to ad hoc requests for short concept papers, letters and the like.

21. The team will also be responsible for responding to donor requests for progress and other such reports which may be in a form specified by individual donors. For example, the World Bank has a standard form to report on procurement activities (see attached Quarterly Procurement Status Report for the World Bank Funded/Administered Projects). This is to be prepared and submitted within seven days from the end of a quarter to, among others, the Grant Management Unit at the Ministry of Finance.

\section{Facilities Provided by the Client}

22. The Ministry of Water and Power will make available office space for the PISU where the team including its counterparts will operate. The firm should be aware that no equipment or office furniture will be provided for the team including its counterparts (expected to total fifteen in number).

\section{Conflict of Interest}

23. The bidder shall expressly declare that he will not participate in any tendering organised by the above outlined MWP Programme Implementation Support Unit. 


\title{
5. Case-Study: Urban Water Supply and Sanitation (MUDH)
}

\author{
Sector Development Plans and TA requirements \\ Brief prepared for the October 23 workshop (DRAFT) \\ Background
}

Due to the long period of conflict, no major investment has been made in the urban water supply and sanitation sector since the mid 1970s. Thirty years later, the population of the major cities has been multiplied by four to five times, many villages have become cities. As a result of the backlog of investments, at less than $20 \%$ the current coverage of safe water supply and sanitation services in urban Afghanistan is the lowest in the world.

\section{Government strategy}

The Government strategy since the end of the conflict has been to focus on the rehabilitation and reestablishment of existing water supply and sanitation services, while at the same time initiate capacity building and institutional strengthening, and carry out feasibility studies for system expansion. The implementation of a scaled up program of investments to increase coverage of WSS services throughout Afghanistan will require both the Urban Ministry (MUDH) and sector institutions to substantially strengthen their capacities to plan and implement. The purpose of this brief is to outline possible proposals to address this issue.

\section{Current Activities and TA}

The main contributors to the UWSS'sector since 2002 are the German Bank for Reconstruction (KfW) and IDA. Several other agencies and NGOs are also funding smaller schemes in most Afghan cities. Key activities include:

1. Kabul water supply (about $\$ 11 \mathrm{~m}$ of $\mathrm{KfW}$ funding)

- Design and implementation of immediate rehabilitation measures during 2002-2003 (\$10 m of $\mathrm{KfW}$ funding)

- Feasibility study for the extension of the Kabul Water Supply system, including technical, economic and institutional aspects, and a medium-term (horizon 2009) and long-term (horizon 2015) investment plan. Study to be completed by the end of 2003, workshop on Nov. 1-2, 2003. The study will serve as a basis for the appraisal of a follow-on project to be funded by $\mathrm{KfW}$ (about $\$ 8 \mathrm{~m}$ ), and possible co-financing from IDF; $\mathrm{ARTF}$ and other donors.

- (more details/update to be provided by KfW)

2. Kabul sanitation (including excreta disposal/wastewater, solid waste management and drainage) (about $\$ 3 \mathrm{~m}$ of IDA funding)

- Design and implementation of short-term rehabilitation and pilot projects during 2004, including initial capacity building measures

- Preparation of a Strategic Sanitation Plan, including (i) a rapid review exercise to inform the design of the short-term priority plan, (ii) detailed studies and strategic planning to inform the design of a mid-term investment plan (horizon 2007), (iii) preparation of a Sewerage/Drainage Master Plan to include a long term investment plan (horizon 2015). The study will serve as a basis for the preparation of a follow-on project, possibly financed by IDA and other donors.

- Possible additional services (to be decided during 2004) include: (i) engineering design of first tranche (to be implemented in 2005-2007) of sewerage/drainage master plan, and (ii) detailed engineering and environmental design for a permanent solid waste disposal site in Kabul. 
3. Western Region WSS (Herat, Farah, Qala-E-Now/Badghis, Chaghcharan/Ghor) (about $\$ 9$ million of $\mathrm{KfW}$ funding)

- Design and implementation of short-term rehabilitation measures, and a mid-term expansion plan during 2003-2005 ( $\$ 8.5$ million of $\mathrm{KfW}$ funding)

$\therefore \quad$ (more details/update to be provided by KfW)

4. Northern Region WSS (Mazar, Shiberghan, Kunduz, Taloqan), Eastern Region WSS (Jalalabad, Mehterlam, Charikar, Gardez, Ghazni), Southern Region WSS (Kandahar, Qalat) (about \$11 million of IDA funding + proposed additional \$5m during 2004)

- Design and implementation of short-term rehabilitation and system redesign measures

- Systems operation and management support, including (i) operating assets replenishment, (ii) management support and training, (iii) water quality surveillance, (iv) financials, billing and collection, and (v) monitoring and evaluation

- Planning for future operations, including (i) feasibility studies for system expansion for the 11 towns covered under the investment project, and (ii) institutional study, sector/nationwide and for the provincial towns. These studies will serve as a basis for the preparation of a follow-on project, possibly financed by IDA and other donors.

- Assessment and planning of sanitation facilities

- Potential Additional Services: feasibility studies in other towns not covered by piped supplies (to be decided and carried out in early 2004)

\section{TA and sector development}

- Institutional studies, nationwide, for Kabul and the provincial towns (funded by KfW and IDA)

- Integrated water resources management TA, implemented by MIRWE and funded by GTZ

- Provision of advisors within MUDH (with German and Italian funding)

\section{Proposals for future sector development \\ 1}

Given that the major urban centers in Afghanistan are currently covered under design-construction contracts (with partial operational support), and feasibility studies have/will be carried out in all urban centers, it is proposed to continue this approach - accompanied by strengthening of capacity building and operational support - while longer-term institutional measures are being prepared. Under this scenario, CAWSS would be corporatized and regionalized before private operators take over utility management in early 2006 (see draft proposal). Accordingly, TA support to the sector would include:

1) Immediately, the recruitment of 2 senior advisors who woule, (ToR being drafted): .

- Assist MUDH on matters of policy and sector development issues, particularly for the (ongoing) institutional studies, funded by KfW and IDA

- Assist CAWSS on operational and technical issues, particularly the supervision of the 3 major contracts funded by KfW and IDA

2) The proposed Consultancy to support MUDH to include support to water supply and sanitation, including sector coordination, and oversight of the design, construction and operational work carried out by the Consultants currently funded by KfW and IDA.

3) The preparation of the long-term institutional setup, through a Consultancy that would lead to the recruitment of one or more private operators to manage Kabul and other regional utilities, in a DBO (design-build-operate) format.

4) The ongoing Consultant contracts (funded by KfW and IDA) to be extended by $1-1.5$ years until the private operators are in place. Scope of the contracts would be expanded as needed in terms of capacity building and operational support. 


\section{Draft Proposal}

1. The main objective of the proposed project would be to complete the rehabilitation of systems currently ongoing and expand the coverage of water supply and sanitation service in about cities, which is currently provided by the existing Central Authority for Water Supply and Sewerage (CAWSS) The project would rehabilitate existing facilities, increase production as needed, extend distribution network to selected un-served areas and put in place the basis for sound technical, commercial and financial operations. The project would also rehabilitate and expand sewers and waste water treatment facilities. Detailed designs are being prepared (under KfW and IDA financing) for the rehabilitation and extension of water supply and sanitation systems in Kabul and in about 15 provincial cities.

2. CAWSS would be split into four Regional AWSS in addition to the Kabul area AWSS. Outside of Kabul, each RAWSS would serve an average standpipes (map to be produced)

\section{Management Contract}

3. The Government would request each RAWSS' to enter into a five-year Management Contract with a private Manager to be selected according to a fair and transparent competitive process. The Manager's main tasks would be to:

- Implement the defined rehabilitation and extension program(s) on behalf of the RAWSS including: (a) the review of bidding documents (if necessary); (b) the procurement of goods and works; and (c) the supervision of construction. The construction period would limited to (30) months, out of the 60 months of the Management contract; the Manager would receive a fixed monthly Project Management Fee;

- Operate the WS (and waste water) service including: (a) technical operation of the production and distribution facilities and day to day maintepance; (b) metering, billing and collection; and (c) training of local staff. The Manager would be responsible for operating the WSS system from the beginning of the Management Contract; the Manager would receive a monthly Fixed Operation Fee to cover staff and maintenance costs plus an Variable Operation Fee proportional to the quantity of water sold to caver energy and chemicals costs. The Manager would be paid an Operation Bonus if he exceeds a minimum performance.

4. The Management Contract would be structured in such a way that the Manager is not tempted to leave soon after construction is completed. For this, the Manager should make profit, only if he is paid the Operation Bonus. Project Management and Operation Fees would be set in the Bidding Document at a level just sufficient to cover costs; the bidding would be on the Operation Bonus.

\section{Cost Recovery Strategy}

5. Taking into account local circumstances, the Fixed Operation Fee and the Operation Bonus would fully financed by Donors, and the Variable Operation Fee would be covered by revenues generated from operations. However, the project objective would be to generate revenues sufficient to cover the full cost of the Management Contract by year 5. Tariff would be gradually increased by the Government and collection would be gradually improved by the Manager to achieve this objective. Excess cash generated would be used as counterpart funds for construction contracts. In a second phase (i.e., as of year 6) the Management Contract would be fully financed from revenues.

\footnotetext{
${ }^{1}$ Contracts could possibly be clubbed (e.g. 3 contracts for each Kabul, North and South Afghanistan)
} 


\section{Issues to be Addressed during Project Preparation}

6. Pre-qualification criteria of the Managers: one should first test if international Operators are interested in the proposed arrangement in Afghanistan; having three of them interested would be sufficient. If not, one may have to relax PQ criteria to allow new comers such as Engineering .Consultants; one should avoid pre-qualifying Operators and Consultants together.

7. Review of the Bidding Document for the Management Contract: pre-qualified companies should be closely associated to the preparation of its final draft.

8. Estimation of fixed fees: this task would require the preparation of a detailed financial forecast of the operation. Since the main cost to the Manager is likely to be expatriate staff, estimating fees would be easier if pre-qualified firms are of the same category (European Operators or international Engineering Consultants).

9. Identification of Performance Criteria: key criteria are likely to be related to:

- Permanence of service and quality of water;

- Installation of new connections and standpipes;

- Installation of bulk and individual meters;

- Non Revenue Water and Collection ratio.

10. TOR of the Technical Auditors: they would certify the amount of the Project Management, Fixed and Variable Operation Fees and Operation Bonus to be paid.

11. Contractual issues: the clause on compensation in case of early ternination of the Management Contract would have to be drafted carefully.

12. OBA type of financing: the Operation Bonus is a type of OBA.

13. Number of Management Contracts one pre-qualified company can be awarded. It is likely that only a limited number of firms may be interested and that more than one contract would have to be awarded to one firm.

Possible Project Timeline

January 2004

September 2004

December 2004

March 2005

August 2005

October 2005

December 2005

January 2006
Initiate procurement of PSP Consultant/ Transaction advisor PSP Consultant / Transaction advisor place

Start pre-qualification process

Draft contract and pre-qualification process completed

Call for proposals (RfP)

Submission of proposals .

Evaluation and negotiations

Contract(s) signature and mobilization

Ongoing rehabilitation contracts funded by KfW in Kabul (water supply) and Western Region, and by IDA in Kabul (sanitation), Northern, Southern and Eastern Regions would be extended by 11.5 year until private operators are in place. 


\section{B. Agenda (English)}

\section{Workshop on Capacity-Building for National Development Programs in Selected Infrastructure Sectors}

Transitional Islamic State of Afghanistan, Asian Development Bank and World Bank

October 23, 2003

Venue: Afghanistan Assistance Coordination Authority

9:00-9:05

$9: 05-9: 15$

$9: 15-9: 30$

$9: 30-10: 15$

$10: 15-11: 30$

$11: 30-12: 00$
Registration, Coffee and Tea

Welcome, World Bank and Asian Development Bank

Introductory remarks, H.E. Eng. M. Masoom Stanekzai (Minister of Communications)

Part 1: Options Using Priority Reform and Restructuring (PRR)

Presentation explaining the PRR, Eklil Hakimi (IARCSC)

Case-study, Technical Advisor Mr. Ehsan Nawabi

(Ministry of Public Works)

Plenary discussion, chaired by H.E. Eng. M. Masoom Stanekzai

\section{Part 2: Options for Complèmentary Short-term Actions}

Case-study: Ministry of Water and Power, H.E. Dr. Ghulam Jelani Jelis (Deputy Minister of Water and Power)

Plenary discussion, chaired by H.E. Dr. Ashraf Ghani Ahmadzai (Minister of Finance)

\section{Part 3: Next Steps}

Presentation explaining how the Ministries should proceed, H.E. Mr. Mohmad Amin Farhang (Minister of Reconstruction)

Plenary discussion, chaired by H.E. Mr. Mohmad Amin Farhang 


\section{Template for Short-Term Capacity-Building Plan (Dari)}

\section{نمونه براي بِلن اعمار مهارت كوتاه مدت}

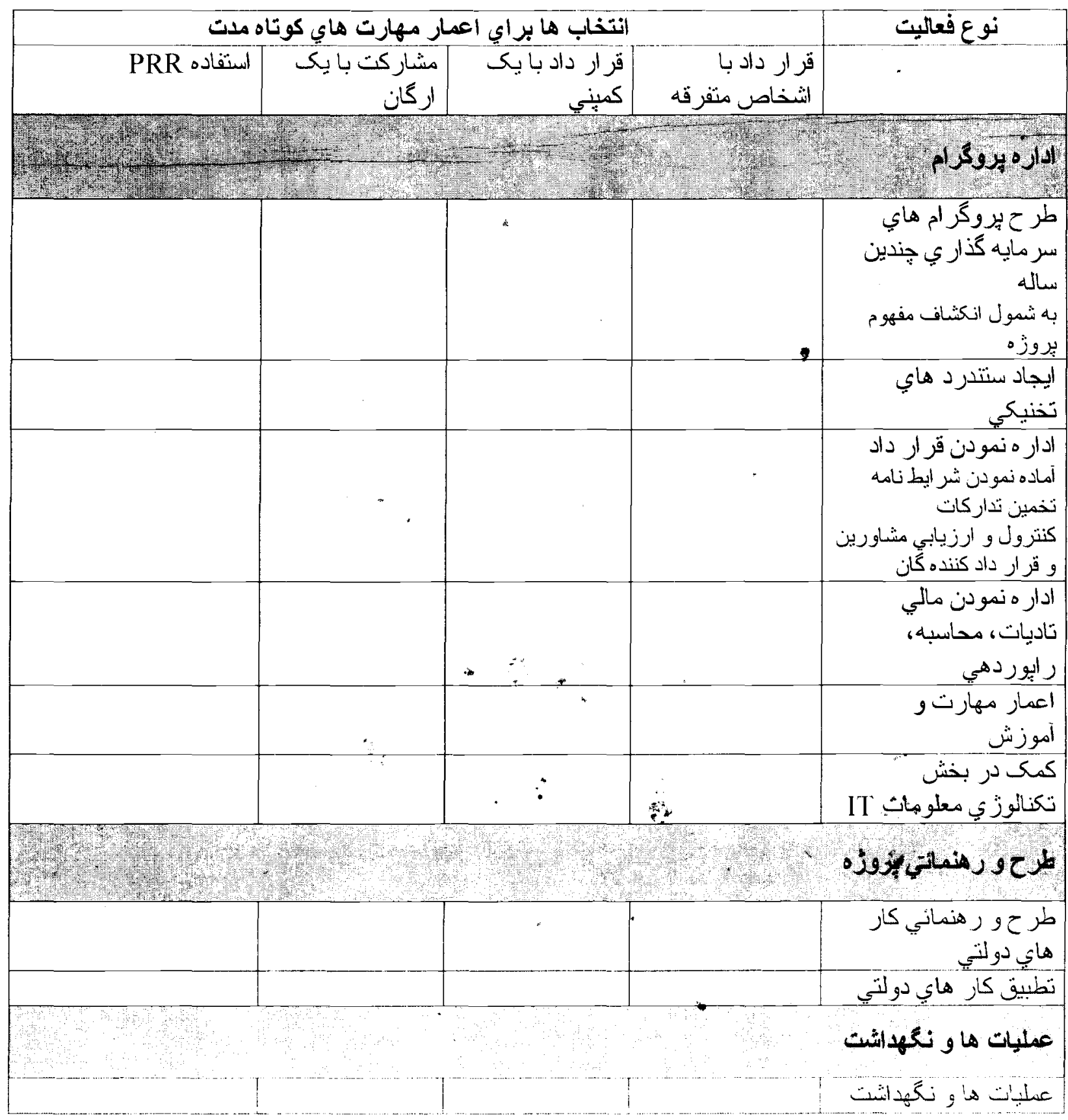




\section{Template for Short-Term Capacity-Building Plan (English)}

\begin{tabular}{|c|c|c|c|c|}
\hline \multirow{2}{*}{ Function } & \multicolumn{4}{|c|}{ Options for short-term capacity-building } \\
\hline & $\begin{array}{l}\text { Contracting } \\
\text { individuals }\end{array}$ & $\begin{array}{l}\text { Contracting } \\
\text { a firm }\end{array}$ & $\begin{array}{l}\text { Partnership } \\
\text { with an agency }\end{array}$ & Use of PRR \\
\hline \multicolumn{5}{|l|}{$\begin{array}{l}\text { Program } \\
\text { Management }\end{array}$} \\
\hline \multicolumn{5}{|l|}{$\begin{array}{l}\text { Multi-Year Investment } \\
\text { Programming } \\
\text { (including project concept } \\
\text { derclopment) }\end{array}$} \\
\hline \multicolumn{5}{|l|}{$\begin{array}{l}\text { Setting Technical } \\
\text { Standards }\end{array}$} \\
\hline $\begin{array}{l}\text { Contracts Management } \\
\text { (preparing TOR. } \\
\text { procurement oversight. } \\
\text { monitoring and supervising } \\
\text { consultants and contractors) }\end{array}$ & & * & & \\
\hline $\begin{array}{l}\text { Financial Management } \\
\text { (palyments. accounting. } \\
\text { reporting) }\end{array}$ & & & 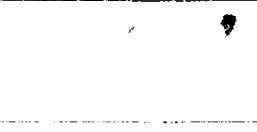 & \\
\hline \multicolumn{5}{|l|}{$\begin{array}{l}\text { Capacity-Building and } \\
\text { Training }\end{array}$} \\
\hline \multicolumn{5}{|l|}{ II Support } \\
\hline \multicolumn{5}{|l|}{$\begin{array}{l}\text { Project Design and } \\
\text { Supervision }\end{array}$} \\
\hline $\begin{array}{l}\text { Civil Works Design } \\
\text { and Supervision }\end{array}$ & $\star$ & $\because \quad$ & . & \\
\hline $\begin{array}{l}\text { ('ivil Works } \\
\text { Implementation }\end{array}$ & $\because$ & $\therefore$ & & $\because$ \\
\hline $\begin{array}{l}\text { Operations and } \\
\text { Maintenance }\end{array}$ & & & 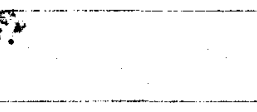 & \\
\hline $\begin{array}{l}\text { Operations and } \\
\text { Maintenance }\end{array}$ & & r & & \\
\hline
\end{tabular}


E. Key Functions of Capacity

\section{Key Functions of Capacity Required, and Short-Term Options to Complement Civil Service}

\section{Key Functions}

\section{Program Management}

- Preparing and prioritizing MultiYear Investment Program

- Setting Technical Standards

- Contracts Administration (Terms of Reference, bid evaluation, negotiations, supervision, etc.)

- Financial Management (Payments to consultants and civil works contractors, accounting, financial reporting)

- Capacity-Building (i.e., leaving behind functional ministry after contrảct ends)

\section{Technical Design and Supervision}

Operations and Maintenance

Sector Policy and Institutional Reform

\section{Options for Discussion}

- Twinning with foreign Public Sector Authority (e.g., US Corps of Engineers, Federal Aviation Authority, etc)

- Contracting Individuals

- Contracting a Management Firm
- One vs. Several Contracts

- Possible types of contract:

- Framework contract showing minimum volume of work, adding to scope as needed

- Retainer and bidding for each contract

- Design and Supervise contracts

vs. Design and Build. 


\section{F. Workshop Attendees}

Sector Ministries

- Ministry of Clvil Aviation \& Tourism

- Mr. Jahid Azimi (Deputy Minister)

- Mr. Sayed Kabir Zewari (President of Technical Department)

- Mr. Rassuli (President of Planning Department)

- Mr. F.M. Fedawi (Ariana)

- Mr. M. Shabir

- Ministry of Irrigation, Water Resources \& Environment

- Mr. Daniel Gunaratnam (Advisor)

- Mr. Qaseem Naimi

- Mr. Pir M. Azizi

- Ministry of Public Works

- Dr. Abdullah Ali (Minister)

- Dr. Muhammed Yaquob Shaghasi (Deputy Minister)

- Mr. Sayed Hashemyan (Advisor)

- Abdul Bari Khaliki (Advisor) *

- Mr. Salik (Head of Engineering and Projects Department)

- Mr. Zahad (Head of Maintenance Department)

- Mr. Ehsan Nawabi (USACE Technical Advisor)

- Col. Richard Conte (USACE Central Asia Engineer)

- Ministry of Urban Development \& Housing

- Mr. Nasir Saberi (Deputy Minister)

- Mr. Sharif Hossainy

- Ministry of Water and Power

- Dr. Ghulam Jelani Jelis (Deputy Minister for Power)

- Eng. M. Younus Nawandish (Deputy Minister for Construction)

- Mr. Axel Werner (Advisor)

- Eng. Rabbani (Head of Planning)

- Mr. Ed Elrahal (Bearing Point)

- Eng. Gullajam

Other Ministries and Agencies

- Civil Service Commission (IARCSC)

- Mr. Eklil Hakimi (Head of Office)

- Mr. M. Nadir Hotak

- Ministry of Communication

- Eng. M. Masom Stanekzai (Minister)

- Mr. A. Fatah (Advisor)

- Ministry of Finance

- Dr. Ashraf Ghani Ahmadzai (Minister)

- Ms. Seema Ghani

- Ministry of Reconstruction

- Pohand Dr. Nazid Ahmad Shahidi (Deputy Minister for Professional)

- Mr. Doran Zamer

- Mr. M. Yousuf Shirzai

- Ministry of Rural Rehabilitation and Development

- Mr. Peter Robertson (Advisor)

\section{Donors}

- Asian Development Bank

- Mr. Craig Steffenson

- Mr. Allan Kelly (Project Implement Officer)

- Mr. Salim Qayum (Finance Officer)

- Bearing Point

- Mr. Afzul Rashid

- CIDA (Canada)

- Ms. Nipa Banerjee (Country Director) 
- Crown Agents/Government Procurement Unit

- Mr. David Knevett (Programme Manager)

- Ms. Mihaela Gavrila (Procurement Advisor)

- DFID

- Mr. Richard Hogg (Head of Office)

- DFSU

- Mr. Ahmad Wali Shairzay (Project Manager)

- EC

- Mr. Daud Ahmad (Consultant)

- ICAO

Mr. Arnaud Cauchois (Food Security Expert)

- Mr. Ossi Komppa (Regional Director)

- Mr. Amar Nath Srivastava (CNS Expert)

- Italy

- Mr. Giuseppe Fedele (Attache)

- JICA (Japan)

- Ms. Yoshie Koshikawa (First Secretary, Embassy of Japan)

- Mr. Tomonori Kikuchi (Deputy Resident Representative, JICA)

- Mr. Shoji Hasegawa (Aid Coordination Advisor)

- Mr. Ahmad Zubair

- Norway

- Ms. Nina Schjelderup (Second Secretary)

- SIDA (Sweden)

- Mr. Jorgen Persson (Counsellor)

- UN-HABITAT

- Mr. Mohammad Sharif

- Mr. Najib Amiri

- Mr. Friedrich Affolter

\section{- UNOPS}

- Mr. Gary Helseth (Country Coordinator)

- USAID/US Embassy
- Mr. Robert Wilson (Acting Mission Director, USAID)
- Ms. Shannon Ross (Embassy)
- Mr. Osvaldo Juvier (USAID)
- Lt. Col. Robert Martinez (CMCOORD, CJCMOTF)

- World Bank
- Mr. Philippe Dongier (Manager)
- Mr. Nick Manning (Lead Public Sector Management Specialist)
- Ms. Anne Tully (Acting Country Manager)
- Ms. Julie Fraser (Senior Financial Analyst)
- Mr. Qahir Haidari (Operations Officer)
- Mr. Terje Wolden (Senior Transport Specialist)
- Mr. Satendra Prasad (Consultant)
- Mr. Nils Bruzelius (Consultant)
- Mr. Lyn Debevoise (Consultant)
- Mr. Najib Sharif (Translator) 


\section{Annexes}

\section{ANNEX 1}

Afghanistan UWSS Sector Development (DRAFT)

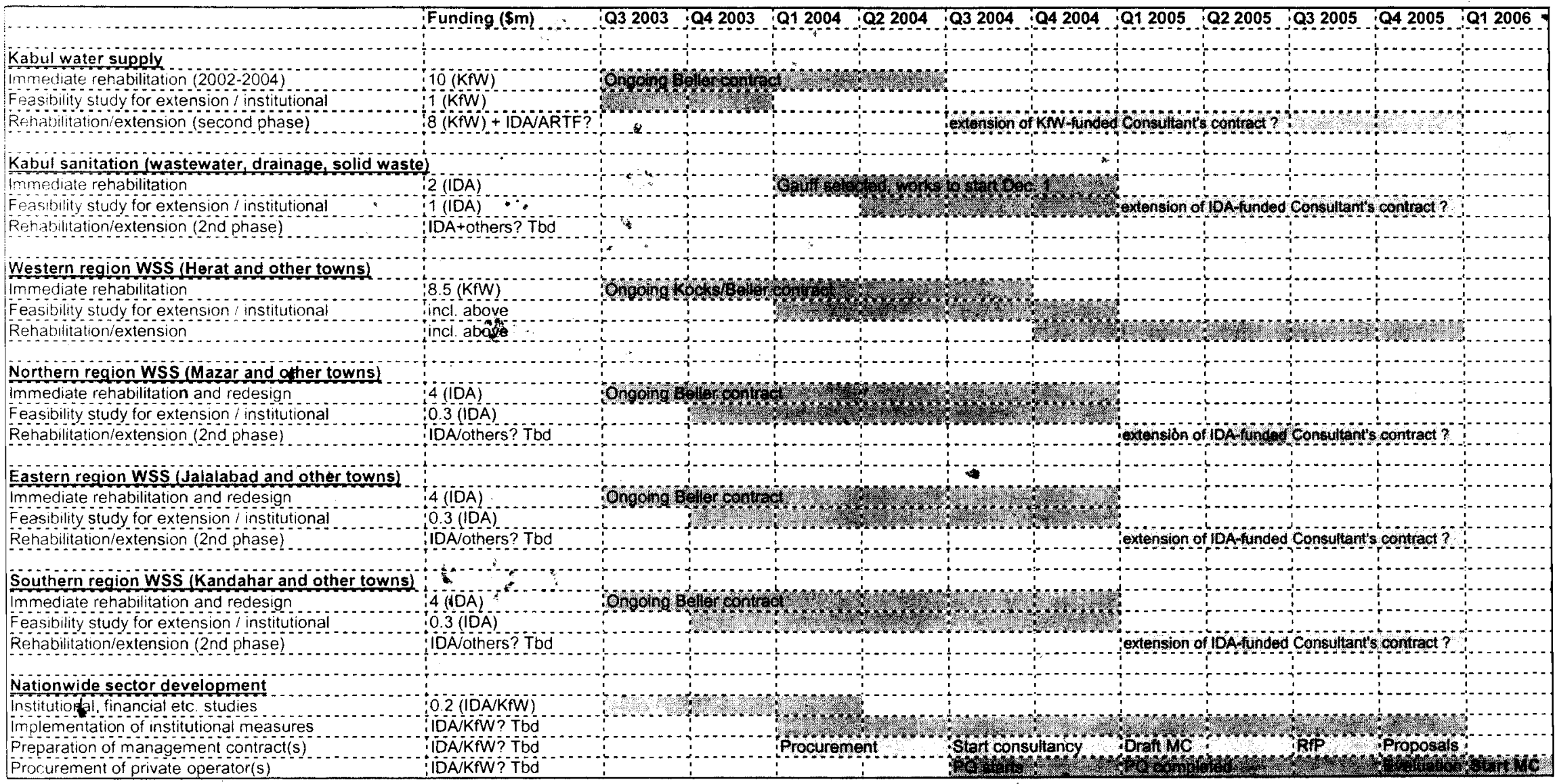




\section{ANNEX 2}

Ministry of Water and Power

\section{Activities of the Programme Implementation Suppoprt Unit}

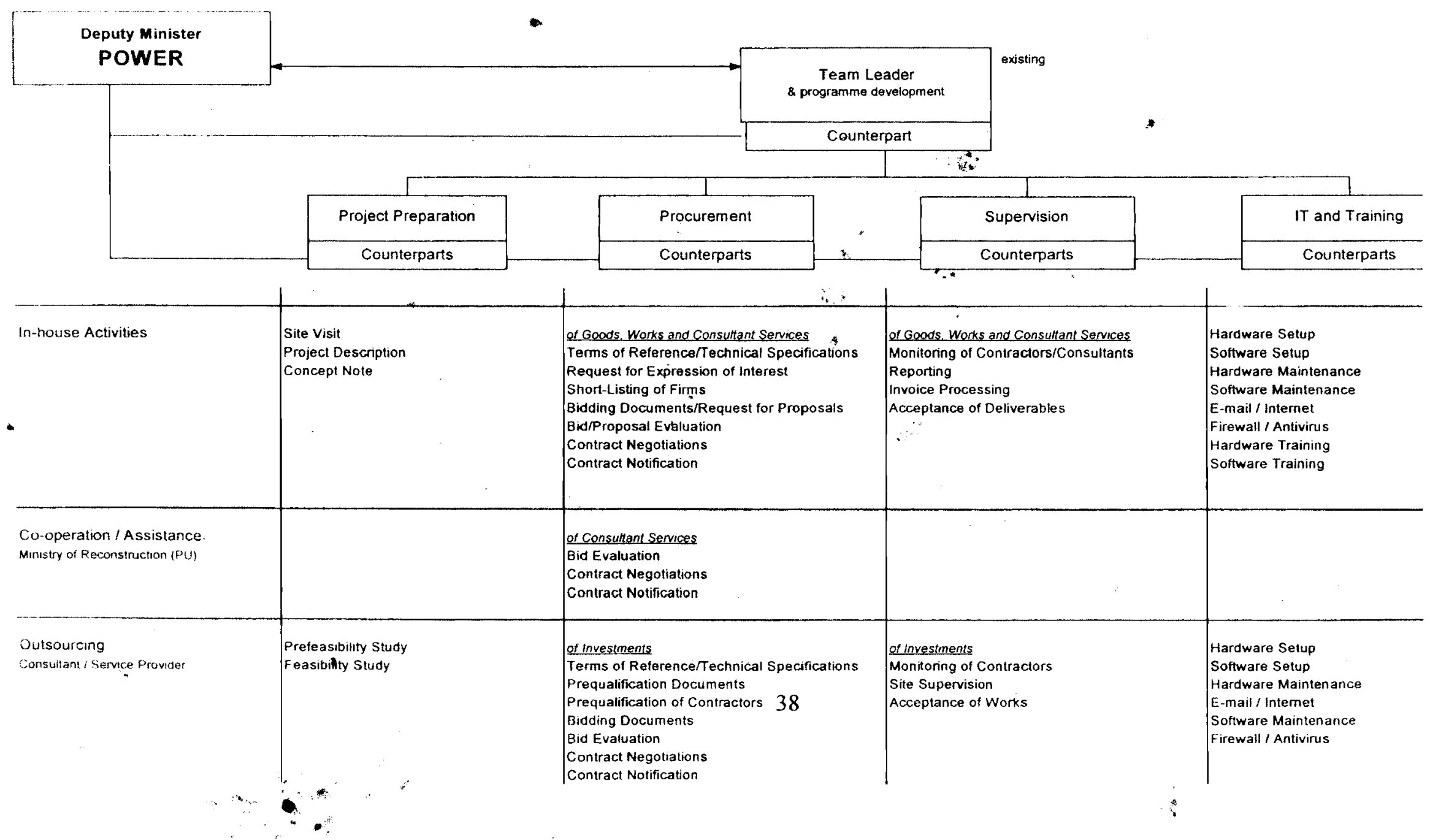


TABLE 1: PROCUREMENT OF GOODSWORKS

PROCUREMENT PLANNING AND MONITORING TABLE

\begin{tabular}{|c|c|c|c|}
\hline RFF\#\# & Description & Estimate (US\$) & $\begin{array}{l}\text { Procurement } \\
\text { Method }\end{array}$ \\
\hline & & & \\
\hline
\end{tabular}

\begin{tabular}{|c|c|c|c|c|c|c|c|c|}
\hline \multicolumn{7}{|c|}{ TIME SCHEDULE (Dates) } & \multirow{2}{*}{$\begin{array}{l}\text { Contract } \\
\text { Ant US\$ }\end{array}$} & \multirow{2}{*}{$\begin{array}{c}\text { Supplier } \\
\text { Name }\end{array}$} \\
\hline $\begin{array}{l}\text { Start Doc } \\
\text { Prep. }\end{array}$ & Advertise & $\begin{array}{c}\text { Bid } \\
\text { Invitation }\end{array}$ & $\begin{array}{c}\text { Bid } \\
\text { Opening }\end{array}$ & $\begin{array}{l}\text { Evaluation } \\
\text { Complete }\end{array}$ & $\begin{array}{c}\text { Contract } \\
\text { Signed } \\
\end{array}$ & $\begin{array}{l}\text { Final } \\
\text { Delivery }\end{array}$ & & \\
\hline & & & & & & & & \\
\hline & & & & & & & & \\
\hline & & & & & & & & \\
\hline & & & & & & & & \\
\hline & & & & & & & & \\
\hline
\end{tabular}

4

$\cdots$

Name of the Progect:

TABIE 2: SELECTION OF CONSULTANTS /

\begin{tabular}{|c|c|c|c|c|c|c|c|c|c|c|c|c|c|c|}
\hline \multirow[t]{2}{*}{ REF\# } & \multirow[t]{2}{*}{ Lescrnption } & \multirow[t]{2}{*}{ Lstimate (US\$) } & \multirow{2}{*}{$\begin{array}{l}\text { Selection } \\
\text { Method }\end{array}$} & \multicolumn{9}{|c|}{ TIME SCHEDULE (Dates) } & \multirow{2}{*}{$\begin{array}{c}\text { Contract Amt } \\
\text { US\$ }\end{array}$} & \multirow{2}{*}{$\begin{array}{c}\text { Cons/Firms } \\
\text { Name }\end{array}$} \\
\hline & & & & 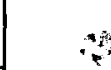 & Advertise & $\begin{array}{l}\text { Start RFP Doc } \\
\text { Preparation }\end{array}$ & $\begin{array}{l}\text { Send out } \\
\text { RFP }\end{array}$ & $\begin{array}{l}\text { Tech Prop } \\
\text { Opening }\end{array}$ & $\begin{array}{l}\text { T Evaluation } \\
\text { Complete }\end{array}$ & $\begin{array}{l}\text { Final Eval } \\
\text { Complete }\end{array}$ & $\begin{array}{c}\text { Contract } \\
\text { Signed }\end{array}$ & $\begin{array}{l}\text { Complete } \\
\text { Assignment }\end{array}$ & & \\
\hline & & 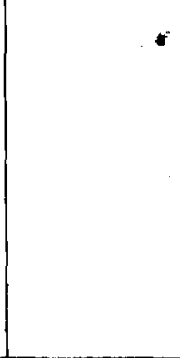 & & $\begin{array}{l}\text { Plan } \\
\text { Actual } \\
\text { Plan } \\
\text { Actual } \\
\text { Plan } \\
\text { Actual } \\
\text { Plan } \\
\text { Attual }\end{array}$ & 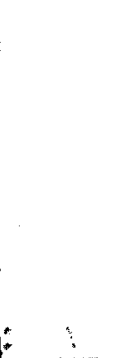 & & & e & 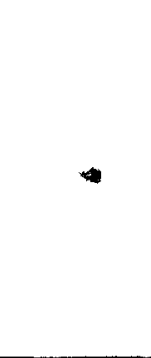 & & & & & \\
\hline
\end{tabular}

Notes - 1. Pror neview thresholds: Consultants US\$...... for firms and US\$ ....... for individuals 